\title{
N-Acetyl-L-Cysteine Protects Astrocytes against Proteotoxicity without Recourse to Glutathione
}

\author{
Amanda M. Gleixner, Daniel F. Hutchison, Sara Sannino, Tarun N. Bhatia, Lillian C. Leak, \\ Patrick T. Flaherty, Peter Wipf, Jeffrey L. Brodsky, and Rehana K. Leak \\ Division of Pharmaceutical Sciences, School of Pharmacy, Duquesne University, Pittsburgh, Pennsylvania (A.M.G., D.F.H., T.N. \\ B., L.C.L., P.T.F., R.K.L.); and Departments of Biological Sciences (S.S., J.L.B.) and Chemistry and Pharmaceutical Sciences, \\ University of Pittsburgh, Pittsburgh, Pennsylvania (P.W.)
}

Received July 17, 2017; accepted August 17, 2017

\section{ABSTRACT}

$N$-acetyl-L-cysteine (NAC) exhibits protective properties in brain injury models and has undergone a number of clinical trials. Most studies of NAC have focused on neurons. However, neuroprotection may be complemented by the protection of astrocytes because healthier astrocytes can better support the viability of neurons. Here, we show that NAC can protect astrocytes against protein misfolding stress (proteotoxicity), the hallmark of neurodegenerative disorders. Although NAC is thought to be a glutathione precursor, NAC protected primary astrocytes from the toxicity of the proteasome inhibitor MG132 without eliciting any increase in glutathione. Furthermore, glutathione depletion failed to attenuate the protective effects of NAC. MG132 elicited a robust increase in the folding chaperone heat shock protein 70 (Hsp70), and NAC mitigated this effect. Nevertheless, three independent inhibitors of Hsp70 function ablated the protective effects of NAC, suggesting that NAC may help preserve Hsp70 chaperone activity and improve protein quality control without need for Hsp70 induction. Consistent with this view, NAC abolished an increase in ubiquitinated proteins in MG132-treated astrocytes. However, NAC did not affect the loss of proteasome activity in response to MG132, demonstrating that it boosted protein homeostasis and cell viability without directly interfering with the efficacy of this proteasome inhibitor. The thiol-containing molecules L-cysteine and D-cysteine both mimicked the protective effects of NAC, whereas the thiol-lacking molecule $N$-acetyl-S-methyl-L-cysteine failed to exert protection or blunt the rise in ubiquitinated proteins. Collectively, these findings suggest that the thiol group in NAC is required for its effects on glial viability and protein quality control.

\section{Introduction}

Neurodegenerative diseases such as Parkinson's disease and Alzheimer's disease are characterized by an imbalance in protein homeostasis, or proteostasis (Walker et al., 2006; Dickson, 2009; Jellinger, 2009; Uversky, 2009; Angot et al., 2010; Xilouri and Stefanis, 2010). Severe imbalances in proteostasis can elicit proteotoxic stress, inclusion formation, and cell death because of widespread protein misfolding and aggregation. In addition to the accumulation of misfolded proteins in neurodegenerative conditions, the activity of the ubiquitin-proteasome system is lower in postmortem brain tissue from patients with Huntington's, Parkinson's, and Alzheimer's disease (Keller et al., 2000; López Salon et al., 2000; Keck et al., 2003; McNaught et al., 2003; McNaught,

These studies were supported by the National Institutes of Health National Institute of Neurologic Disorders and Stroke [Grants R15NS093539 and R03NS088395], National Institute of Diabetes and Digestive and Kidney Diseases [Grant DK79307], and National Institute of General Medical Sciences [Grant GM067082]; the Henry Hillman foundation [Grant 109033]; the Pennsylvania Department of Health [CURE Award 4100062204]; and an EMBO long-term postdoctoral fellowship [ALTF 823-2016].

The authors have no conflicts of interest.

https://doi.org/10.1124/mol.117.109926.
2004; Seo et al., 2004; Mishto et al., 2006). These effects have been modeled in vitro and in vivo with the use of proteasome inhibitors, which lead to the accrual of damaged proteins and cell death through loss of proteostasis (Rideout et al., 2001, 2005; Rideout and Stefanis, 2002; Fornai et al., 2003, 2006; Sawada et al., 2004; Sun et al., 2006; Pan et al., 2008; Xie et al., 2010; Zhu et al., 2010; Li et al., 2012; Zhang et al., 2012; Le et al., 2014).

Most studies of proteotoxicity in the central nervous system have examined neurons because this cell type is known to accumulate protein inclusions (Braak and Braak, 1995; Braak et al., 2003). Furthermore, most therapeutic central nervous system compounds have been tested with respect to their effects on neurons. However, astrocytes can also contain misfolded or aggregated proteins in neurodegenerative disorders. For example, astrocytes may phagocytose $\alpha$-synuclein from the extracellular space (Lee et al., 2010) and are known to exhibit $\alpha$-synuclein ${ }^{+}$inclusions in Parkinson's disease (Wakabayashi et al., 2000; Braak et al., 2007). In Alzheimer's disease, astrocytes are hypothesized to phagocytose extracellular $\beta$-amyloid (Wyss-Coray et al., 2003) and are immunolabeled by anti-A $\beta$ antibodies (Akiyama et al., 1996, 1999;

ABBREVIATIONS: AMC, 7-amino-4-methylcoumarin; DRAQ5, deep red anthraquinone 5; GSH, glutathione; HO1, heme oxygenase 1; Hsc70, heat shock cognate 70; Hsp70, heat shock protein 70; NAC, $N$-acetyl-L-cysteine; NMC, $N$-acetyl-S-methyl-L-cysteine; PBS, phosphate-buffered saline; PES, pifithrin- $\mu$ (2-phenylethynesulfonamide); TBS, Tris-buffered saline. 
Duyckaerts et al., 2009). Astrocytes also contain protein deposits in amyotrophic lateral sclerosis (Yang et al., 2003; Yokota et al., 2006; Yang and Strong, 2012), supranuclear palsy, corticobasal degeneration, and Pick's disease (Komori, 1999). Furthermore, astrocytes may exhibit higher expression of heat shock proteins in neurodegenerative disorders, another indicator of proteotoxic stress (Lowe et al., 1992; Renkawek et al., 1993, 1994a,b, 1999; Shinohara et al., 1993; Dabir et al., 2004; Wilhelmus et al., 2006; Kawamoto et al., 2007; Durrenberger et al., 2009; Seidel et al., 2012). Therefore, previous studies have confirmed that both neurons and glia exhibit loss of proteostasis in neurodegenerative disorders.

The study of proteotoxic stress and chaperone function in astrocytes is important because astrocytes protect neighboring neurons by releasing trophic factors, antioxidants, and metabolic precursors (Allen and Barres, 2009; Kimelberg and Nedergaard, 2010). However, no currently available therapies target astrocytes for protection from proteotoxicity. Thus, the major goal of the present study was to examine the effects of the glutathione (GSH) precursor, $N$-acetyl-L-cysteine (NAC), as a protective agent in astrocytes with diminished proteasome function. NAC has been shown to improve some aspects of cognition in patients with Alzheimer's disease (Adair et al., 2001). Soldiers suffering blast injury in combat experienced a 2 -fold increase in the resolution of their neurologic symptoms when administered NAC within 24 hours of the insult (Hoffer et al., 2013). NAC may also benefit patients with Parkinson's disease; it appears to cross the blood-brain barrier, raise GSH levels, and improve motor deficits and dopamine transporter binding in this condition (Martínez-Banaclocha, 2012; Holmay et al., 2013; Katz et al., 2015; Monti et al., 2016; Reyes et al., 2016). While two previous studies determined that NAC can shield astrocytes from $\beta$-amyloid toxicity (Brera et al., 2000; de Ceballos et al., 2001), it is unknown whether NAC also protects astrocytes against the severe loss of protein quality control associated with proteasome inhibition. To address this gap, we employed the proteasome inhibitor MG132, which has been used to elicit loss of dopaminergic cells and model Parkinson's disease in vivo (Sun et al., 2006; Lu et al., 2010; Xie et al., 2010; Bentea et al., 2017). Clasto-lactacystin $\beta$-lactone and MG132 have been applied in vivo to study the role of the ubiquitin-proteasome system in $\alpha$-synuclein degradation (Ebrahimi-Fakhari et al., 2011). Those studies reveal that $\alpha$-synuclein is degraded by the ubiquitin-proteasome system under both physiologic and pathologic conditions. Furthermore, a large body of work suggests that pathologic $\alpha$-synuclein blocks the activity of the proteasome particle, and that it might be a trigger leading to loss of proteasome activity in Parkinson's disease (Stefanis et al., 2001; Petrucelli et al., 2002; Snyder et al., 2003; Lindersson et al., 2004; Chen et al., 2005, 2006; Jiang et al., 2007; Zhang et al., 2008; Emmanouilidou et al., 2010; Ebrahimi-Fakhari et al., 2011). Collectively, previous studies support inhibition of proteasome degradation as a means of modeling neurodegenerative conditions.

We recently showed that NAC protects neuroblastoma cells and primary cortical and hippocampal neurons against proteotoxic or oxidative stress, perhaps by raising the concentration of the antioxidant GSH (Unnithan et al., 2012, 2014; Posimo et al., 2013; Heinemann et al., 2016). Indeed, most studies of NAC assume that it is effective because it provides a critical precursor, cysteine, for GSH biosynthesis
(Martínez-Banaclocha, 2012; Pocernich and Butterfield, 2012). However, NAC has also been shown to protect cells through extracellular signal-regulated kinase phosphorylation and mitogen-activated protein kinase signaling pathways (Yan and Greene, 1998; Zhang et al., 2011; Sun et al., 2012). Furthermore, NAC can reduce disulfide bonds in protein aggregates (Sheffner, 1963; Samuni et al., 2013). We previously observed that NAC prevented heat shock protein 70 (Hsp70) loss in neuroblastoma cells after treatment with the proteasome inhibitor MG132 (Jiang et al., 2013). Hsp70 is a key contributor to cellular homeostasis, as it facilitates protein refolding, escorts damaged proteins to the proteasome for degradation, and counters apoptosis (Morimoto, 2008; Kalia et al., 2010; Lanneau et al., 2010; Leak, 2014; Fontaine et al., 2016; Ciechanover and Kwon, 2017). Heat shock cognate 70 (Hsc70) is a member of the same chaperone family, and among other functions guides damaged proteins to the lysosome for chaperone-mediated autophagy (Orenstein and Cuervo, 2010; Arias and Cuervo, 2011; Liu et al., 2012). In our previous study on neuroblastoma cells, NAC had no effect on Hsc70 but increased Hsp70 expression, and inhibitors of $\mathrm{Hsp} 70 / \mathrm{Hsc70}$ activity completely abolished the NAC-induced protection (Jiang et al., 2013). Thus, the second goal of the present study was to test the hypothesis that NAC also protects astrocytes in a heat shock protein-dependent manner.

\section{Materials and Methods}

Primary Cultures. All procedures were approved by the Duquesne University Institutional Animal Care and Use Committee and in accordance with the National Institutes of Health "Guide for the Care and Use of Laboratory Animals" (https://www.ncbi.nlm.nih. gov/books/NBK54050/). Protocols for primary cortical astrocyte cultures were adapted from previously published methods (McCarthy and de Vellis, 1980). Briefly, cortical tissue was dissected from postnatal (1 to 2 days old) Sprague-Dawley rats of both genders (Charles River, Wilmington, MA) and incubated in 0.25\% TrypsinEDTA (cat. no. 25200; Gibco Life Technologies, Grand Island, NY) for 8 minutes at $37^{\circ} \mathrm{C}$. Cortical tissue was washed three times in cell culture media (Dulbecco's modified Eagle's medium, cat. no. 12100061; Gibco Life Technologies) containing 10\% Fetal Clone III (cat. no. SH30109.03; Thermo Scientific HyClone, Logan, UT), 44 mM sodium bicarbonate (cat. no. S5761; Sigma-Aldrich, St. Louis, MO), and penicillin/streptomycin $(50 \mathrm{U} / \mathrm{ml}$ and $50 \mu \mathrm{g} / \mathrm{ml}$, respectively; cat. no. 15070; Gibco Life Technologies)]. Tissue was then triturated and plated at a density of 137,143 cells $/ \mathrm{cm}^{2}$ or $24 \times 10^{6}$ cells into T175 flasks (cat. no. 159910; Thermo Scientific, Pittsburgh, PA) coated with poly-D-lysine (10 $\mu \mathrm{g} / \mathrm{ml}$, cat. no. P0899; Sigma-Aldrich). Cultures were maintained at $37^{\circ} \mathrm{C}$ with $5 \% \mathrm{CO}_{2}$. After 7-10 days, flasks were rotated (260 rpm) overnight at $37^{\circ} \mathrm{C}$ to dislodge nonastrocytic cells. Fresh cell culture medium was then added and astrocytes were incubated for an additional 2 to 3 days prior to experimentation. Astrocytes were plated at a density of 20,000 cells/well in 96-well plates (cat. no. 3595; Costar, Corning Inc., Corning, NY) or 680,000 cells/well in $35 \mathrm{~mm}$ dishes (cat. no. DL353001; Falcon, Corning Inc.).

Pharmacological Inhibitors. Proteotoxic stress was induced with the MG132 proteasome inhibitor 24 or 48 hours after plating astrocytes (cat. no. 474790; EMD Millipore, Billerica, MA). MG132 was added in the presence or absence of NAC (cat. no. 160280250; Acros, Geel, Belgium) and the control groups received an equivalent volume of vehicle. The next day, fresh NAC or vehicle was added for an additional 24 hours, after which cell viability was assessed as described subsequently. The same protocol was followed for the L- and D-cysteine experiments, except that NAC was replaced with 
D-cysteine (cat. no. C1329; Tokyo Chemical Industry, Tokyo, Japan) or L-cysteine (cat. no. C12, 180-0; Aldrich Chemical Company, Milwaukee, WI). In addition, control experiments were run in which NAC was replaced with $N$-acetyl-S-methyl-L-cysteine [(NMC); Santa Cruz Biotechnology, Santa Cruz, CA].

Glutathione synthesis was inhibited with buthionine sulfoximine (cat. no. 309475000; Acros) (Griffith, 1982). Buthionine sulfoximine was delivered at a concentration of $25 \mu \mathrm{M}$, based on previous reports that this concentration depletes GSH in astrocytes (Brito et al., 2008; Pizzurro et al., 2014). Hsp70/Hsc70 activity was inhibited with VER155008 (cat. no. 3803; Tocris Bioscience, Minneapolis, MN) (Massey et al., 2010; Saykally et al., 2012; Chatterjee et al., 2013). VER155008 competes for Hsp70 binding ( $\mathrm{IC}_{50}$ value of $\left.0.5 \mu \mathrm{M}\right)$ and has been applied to cells in vitro at concentrations of $10 \mu \mathrm{M}$ in previous studies (Massey et al., 2010; Chatterjee et al., 2013). Hsp70/Hsc70 activity was also inhibited by 2-phenylethynesulfonamide (PES), also known as pifithrin- $\mu$ (cat. no. 506155; EMD Millipore), which has previously been administered to cells at concentrations of $10-20 \mu \mathrm{M}$ (Leu et al., 2009, 2011; Balaburski et al., 2013; Granato et al., 2013; Kondoh and Osada, 2013; Schlecht et al., 2013; Sekihara et al., 2013). Finally, we employed MAL3-101, which has been used to inhibit Hsp70 and increase protein aggregation at concentrations of $10 \mu \mathrm{M}$ or higher (Braunstein et al., 2011; Huryn et al., 2011; Hatic et al., 2012; Kilpatrick et al., 2013; Adam et al., 2014). The structure and method of synthesis of MAL3-101 have been previously published (Fewell et al., 2004). Concentrations higher than those used in the present study were found to be excessively toxic to primary astrocytes. Where indicated, inhibitors were added together with MG132 and NAC. Viability was assessed 48 hours after treatment onset, as described subsequently.

Cell Viability and Immunocytochemistry. Astrocytes were fixed in 3\% paraformaldehyde (cat. no. 9990244; Thermo Scientific) and 3\% sucrose (cat. no. 0389; Sigma-Aldrich) in $75 \mathrm{mM}$ phosphate buffer for 20 minutes and washed three times with $10 \mathrm{mM}$ phosphatebuffered saline (PBS). Cells were then stained with Hoechst 33258 (bisbenzimide, $5 \mu \mathrm{g} / \mathrm{ml}$, cat. no. B1155; Sigma-Aldrich) for 20 minutes. Images of Hoechst-stained nuclei were captured on an EVOS microscope (AMF 4301 US; Advanced Microscopy Group, Bothell, WA). All images were collected from the 3 and 9 o'clock positions in each well. Cell viability was then determined by blinded counts of Hoechst ${ }^{+}$cells using the Image $\mathrm{J}$ software (NIH Image, Bethesda, MD), as described previously (Gleixner et al., 2016).

In addition to counts of Hoechst ${ }^{+}$nuclei, the deep red anthraquinone 5 (DRAQ5) stain for nuclei was also employed in the NMC experiments to assess viability, as described previously (Posimo et al., 2014). Briefly, DRAQ5 was applied as a $0.5 \mu \mathrm{M}$ solution (cat. no. 62251; ThermoFisher Scientific, Pittsburgh, PA) in 0.3\% Triton X-100 for 1 hour to fixed cells, followed by three washes in $10 \mathrm{mM}$ PBS. DRAQ5 levels were then measured on an Odyssey Infrared Imager (LI-COR Biosciences, Lincoln, NE).

For immunocytochemistry, fixed cells were washed in PBS, and exposed for 30 minutes to a fish serum-based blocking solution (cat. no. 927-40000, Odyssey Block; LI-COR Biosciences) diluted 1:1 in PBS and supplemented with $0.3 \%$ Triton $\mathrm{X}-100$. The cells were then incubated overnight at $4^{\circ} \mathrm{C}$ in primary antibodies (see Table 1) diluted in Odyssey Block/PBS (1:1) with $0.3 \%$ Triton X-100 and washed three times with PBS on the following day. Secondary antibodies (see Table 2) were diluted in 50\% Odyssey Block in PBS with $0.3 \%$ Triton X-100 and applied to cells for 1 hour at room temperature. Following secondary antibody incubations cells were washed three times with PBS and immunostaining was captured on an EVOS fluorescent microscope at $200 \times$ magnification.

Total and Reduced Glutathione Measures. Total GSH levels were measured by In-Cell Western analyses and expressed as a fraction of Hoechst-stained nuclei in the same well to control for differences in cell density. This GSH In-Cell Western assay has been validated in previous studies, in which the signal for GSH was successfully decreased with buthionine sulfoximine and increased with NAC (Leak et al., 2008; Unnithan et al., 2012; Posimo et al., 2013; Titler et al., 2013; Gleixner et al., 2016; Heinemann et al., 2016). Reduced GSH levels were measured by the luminescent GSH-Glo assay according to the manufacturer's instructions (cat. no. V6911; Promega, Madison, WI) and as previously described (Gleixner et al., 2016).

Proteasome Activity Assay. Cellular lysates were collected 30 minutes after MG132 and NAC treatment, as previously described (Milan et al., 2015). Proteasome activity was determined by monitoring the production of 7-amino-4-methylcoumarin (AMC) from SucLLVY-AMC (cat. no. I-1395; Bachem, Torrance, CA), an established substrate of the chymotrypsin-like activity of the proteasome (Stein et al., 1996). In brief, $10 \mu$ l of each lysate sample was incubated at $37^{\circ} \mathrm{C}$ with $1 \mu \mathrm{l}$ of the $5 \mathrm{mM}$ stock solution of Suc-LLVY-AMC in $20 \mathrm{mM}$ Tris$\mathrm{HCl} \mathrm{pH} \mathrm{7.5,} 2 \mathrm{mM}$ ATP, $2 \mathrm{mM} \mathrm{MgCl}_{2}$, and $0.2 \%$ bovine serum albumin, in the presence or absence of $10 \mu \mathrm{M}$ MG132 (Selleckchem, Houston, TX) for background (i.e., nonproteasome) subtraction. The fluorescence of released AMC was measured at time 0 and after 30 minutes with a FluoroMax3 plate reader (excitation $380 \mathrm{~nm}$ and emission $460 \mathrm{~nm}$; HORIBA Scientific Instrument \& Systems, Kyoto, Japan).

TABLE 1

Primary antibodies

\begin{tabular}{|c|c|c|c|c|c|c|}
\hline Primary Antibody & Source & Company & Catalog Number & Lot Number & Western Blot Dilution & $\begin{array}{l}\text { Immuno- } \\
\text { Cytochemistry } \\
\text { Dilution }\end{array}$ \\
\hline$\alpha$-Tubulin & Mouse & Sigma-Aldrich & T5168 & $078 \mathrm{~K} 4781$ & $1: 200,000$ & \\
\hline$\beta$-Actin & Mouse & Sigma-Aldrich & A5441 & 030M4788 & $1: 50,000$ & \\
\hline$\beta$-Actin & Rabbit & Sigma-Aldrich & A2103 & 051 M4767 & $1: 1500$ & \\
\hline GAPDH & Rabbit & Cell Signaling Technology & $2118 \mathrm{~S}$ & 8 & $1: 1000$ & \\
\hline GFAP & Rabbit & Dako (Santa Clara, CA) & Z0334 & 00059584 & & $1: 1000$ \\
\hline GSH & Rabbit & EMD Millipore & AB5010 & NG1870405 & & $1: 300$ \\
\hline HO1 & Rabbit & Sigma-Aldrich & H4535 & $081 \mathrm{M} 1122$ & $1: 200$ & \\
\hline Hsc70 & Rat & Enzo Life Sciences (Farmingdale, NY) & ADISPA815 & 04231339 & $1: 5000$ & \\
\hline Hsp25 & Goat & Santa Cruz Biotechnology & sc-1048 & D0312 & $1: 1000$ & \\
\hline Phospho-Hsp25 & Rabbit & Cell Signaling Technology & 2401 & 11 & $1: 500$ & \\
\hline Hsp40 & Rabbit & Cell Signaling Technology & 4868 & 2 & $1: 1000$ & \\
\hline Hsp70 & Mouse & Calbiochem & 386032 & D00126860 & $1: 1000$ & \\
\hline Hsp90 & Rabbit & Cell Signaling Technology & 4877 & 3 & $1: 1000$ & \\
\hline $\mathrm{PA} 28 \alpha$ & Rabbit & Calbiochem (San Diego, CA) & 539146 & D00092184 & $1: 1000$ & \\
\hline PA700 & Rabbit & EMD Millipore & 539147 & D00110930 & $1: 1000$ & \\
\hline $\mathrm{S} 100 \beta$ & Mouse & Sigma-Aldrich & $\mathrm{S} 2532$ & $070 \mathrm{M} 4767$ & & $1: 1000$ \\
\hline Ubiquitinated proteins & Mouse & Santa Cruz Biotechnology & sc- 8017 & D0412 & $1: 500$ & \\
\hline
\end{tabular}

GAPDH, glyceraldehyde-3-phosphate dehydrogenase; GFAP, glial fibrillary acidic protein; Hsp25, heat shock protein 25; Hsp40, heat shock protein 40; Hsp90, heat shock protein 90 
TABLE 2

Secondary antibodies

\begin{tabular}{|c|c|c|c|c|}
\hline Secondary Antibody & Company & Catalog Number & Western Blot Dilution & $\begin{array}{l}\text { Immuno-Cytochemistry } \\
\text { Dilution }\end{array}$ \\
\hline Donkey anti-rabbit 680 & LI-COR Biosciences & $926-32223$ & $1: 20,000$ & \\
\hline Donkey anti-rabbit 800 & LI-COR Biosciences & $926-32213$ & $1: 20,000$ & $1: 1000$ \\
\hline Donkey anti-mouse 680 & LI-COR Biosciences & $926-32222$ & $1: 20,000$ & \\
\hline Goat anti-mouse 800 & LI-COR Biosciences & $926-32210$ & $1: 20,000$ & \\
\hline Donkey anti-goat 800 & LI-COR Biosciences & $926-32214$ & $1: 20,000$ & \\
\hline Goat anti-mouse 488 & Life Technologies (Carlsbad, CA) & A11029 & & $1: 1000$ \\
\hline Goat anti-rabbit 555 & Life Technologies & A 21429 & & $1: 1000$ \\
\hline
\end{tabular}

The assay was calibrated using a standard free fluorophore solution containing increasing amounts of AMC (cat. no. 89160-328; VWR, Randor, PA). All measurements were performed in duplicate and values were normalized to protein content, as determined by the bicinchoninic acid assay according to the manufacturer's instructions (cat. no. 23225; ThermoFisher Scientific). The proteasome activity of each sample was calculated by using the following formula: $\left[\left(\mathrm{RFU} 2-\mathrm{RFU} 2_{\mathrm{MG} 132}\right)-\left(\mathrm{RFU} 1-\mathrm{RFU}_{\mathrm{MG} 132}\right)\right] /[(\mathrm{T} 2-\mathrm{T} 1) \times$ protein concentration].

Immunoblotting. To prepare lysates, cells were harvested 24 or 48 hours following treatments and sonicated in cell lysis buffer (recipe from Cell Signaling Technology, Danvers, MA) supplemented with protease inhibitor cocktail (1:50, cat. no. P8340; Sigma-Aldrich) and $10 \mathrm{mM}$ sodium fluoride (Leak et al., 2010). Equal amounts of protein (as determined by the bicinchoninic acid assay) were separated by gel electrophoresis on $10 \%$ polyacrylamide gels and transferred to Immobilon-FL polyvinylidene fluoride (cat. no. IPFL00010; EMD Millipore) or nitrocellulose membranes (cat. no. 926-31092; LI-COR Biosciences). Membranes were washed three times in Tris-buffered saline (TBS) and blocked with 5\% nonfat dry milk in TBS or Odyssey Block (cat. no. 927-40000; LI-COR Biosciences) diluted 1:1 in TBS. Primary antibodies were diluted in TBS with $0.1 \%$ Tween and 5\% bovine serum albumin fraction V (cat. no. A30075; Research Products International, Mount Prospect, IL) or Odyssey Block diluted 1:1 in TBS with $0.1 \%$ Tween. Secondary antibodies were prepared in TBS with $0.1 \%$ Tween and $5 \%$ nonfat dry milk or in Odyssey Block diluted 1:1 in TBS with $0.1 \%$ Tween. Immunolabeled blots were then washed in TBS with $0.1 \%$ Tween and fluorescent signal was quantified by Odyssey software (version 3.0; LI-COR Biosciences) or Image Studio Lite software (LI-COR Biosciences).

Statistical Analyses. Experiments were conducted in triplicate or quadruplicate wells. The data from individual replicate wells were averaged to yield a value of $n=1$ for that experiment and this was repeated on at least three occasions for a final value of $n=3$ or more.
Statistical significance was determined by two- or three-way analysis of variance followed by the Bonferroni post hoc correction (version 10.0; IBM SPSS Statistics, Armonk, NY). Differences between groups were only deemed significant when $P \leq 0.05$. All data are illustrated as the mean \pm S.E.M.

\section{Results}

NAC Protects Primary Cortical Astrocytes from Proteotoxicity. The proteasome inhibitor MG132 elicited concentration-dependent loss of Hoechst-stained nuclei in astrocyte cultures, and NAC (3 mM) significantly decreased the toxicity of 0.1-0.4 $\mu \mathrm{M}$ MG132 (Fig. 1, A and B). For qualitative assessments of cellular morphology, we employed the astrocyte cytoskeletal markers glial fibrillary acidic protein and $\mathrm{S} 100 \beta$ (Fig. 1C) and observed that NAC ameliorated the morphologic changes in response to MG132, as expected. These findings suggest that NAC prevents glial cell death in response to proteotoxic stress.

One explanation for the reduction in cell loss by NAC may be that it interferes with the impact of MG132 on proteasome activity, rather than protecting against the downstream consequences of proteasome inhibition. For example, NAC might activate protein factors that protect the proteasome from loss of function (Rodriguez et al., 2014). Alternatively, NAC has been shown to bind to the proteasome inhibitors lactacystin and bortezomib and to directly interfere with their effects on the proteasome particle (Halasi et al., 2013). To address these possibilities, we examined proteasome activity levels in NAC- and MG132-treated samples (Fig. 1D). NAC reduced proteasome activity levels when administered on its
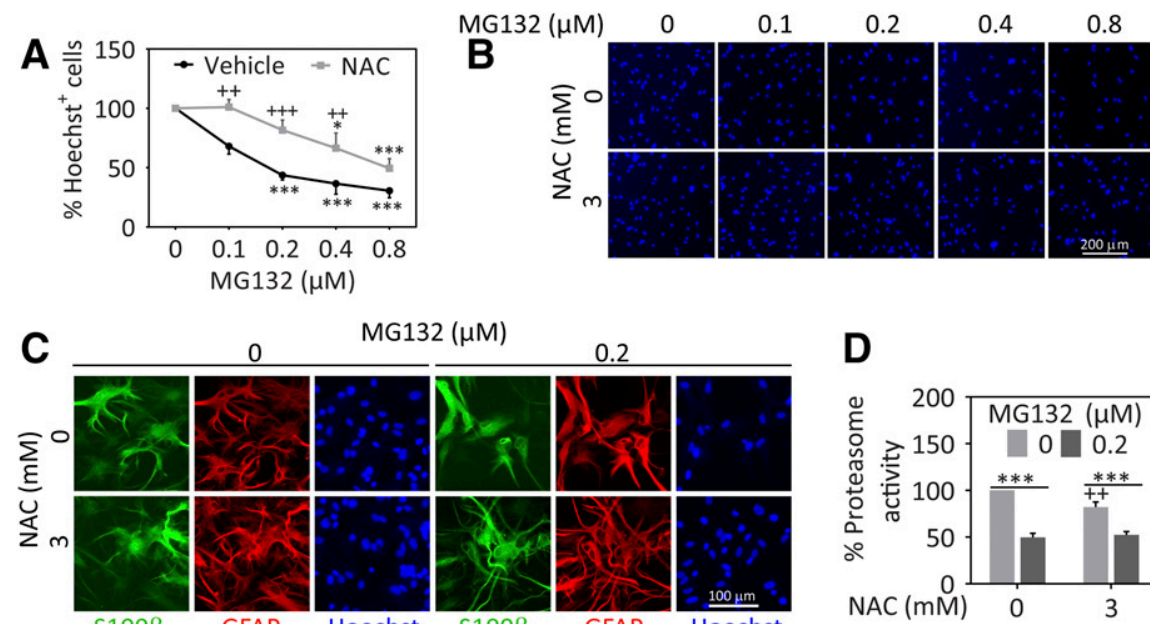
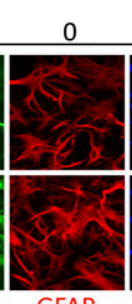

GFAP
MG132 ( $\mu \mathrm{M})$

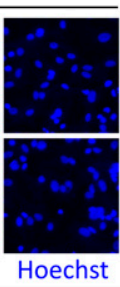

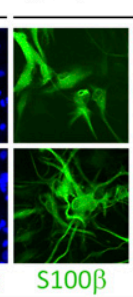

\begin{abstract}
0.2
\end{abstract}

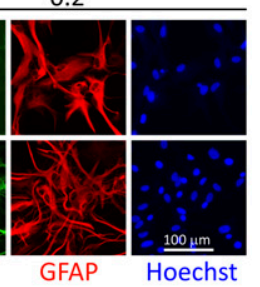

D

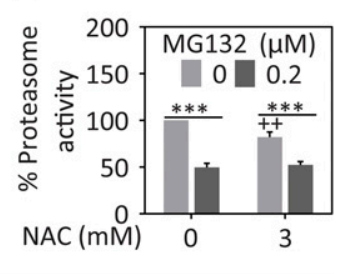

Fig. 1. NAC protects astrocytes from proteasome inhibitor-mediated cell loss. Primary cortical astrocytes were treated with vehicle (dimethylsulfoxide) or a range of MG132 concentrations in the presence of $3 \mathrm{mM} \mathrm{NAC}$ or vehicle (equivalent v/v $\mathrm{H}_{2} \mathrm{O}$ ). (A) Viability was determined 48 hours later by blinded counts of Hoechst ${ }^{+}$nuclei. (B) Representative images of Hoechst ${ }^{+}$nuclei. (C) Representative images of astrocytes stained for $\mathrm{S} 100 \beta$ (green) and glial fibrillary acidic protein (GFAP, red). Nuclei were labeled with Hoechst (blue). (D) Proteasome activity was determined by monitoring the production of AMC from Suc-LLVY-AMC in lysates prepared from cells 0.5 hours after application of NAC, MG132, or their respective vehicles. Proteasome activity data are expressed as a function of protein content in each sample. Shown are the mean \pm S.E.M. values of $3-6$ independent experiments. ${ }^{*} P \leq 0.05 ; * * * P \leq 0.001$ versus $0 \mu \mathrm{M}$ MG132; ${ }^{++} P \leq 0.01 ;{ }^{+++} P \leq 0.001$ versus 0 mM NAC, two-way analysis of variance followed by the Bonferroni post hoc test. 
own, consistent with previous work (Pajonk et al., 2002), but did not exert this effect in the presence of MG132 in our model. Thus, MG132 robustly reduced proteasome activity in the absence or presence of NAC in primary astrocytes, as in our prior studies on neuroblastoma cells (Jiang et al., 2013). Therefore, NAC does not reduce cell loss simply by interfering with the inhibitory effect of MG132 on the proteasome, but protects astrocytes against the toxic sequelae of MG132induced loss of protein degradation.

NAC Protects Astrocytes Independent of Glutathione Synthesis. Previous studies have shown that NAC can increase GSH levels in MG132-treated cells and primary neurons (Posimo et al., 2013; Cheng et al., 2016; Heinemann et al., 2016) as well as untreated astrocytes (Jurkowska and Wróbel, 2008). Therefore, we assessed GSH levels in MG132and NAC-treated astrocytes. MG132 increased intracellular GSH levels, but NAC attenuated this rise (Fig. 2A). To confirm these results, we performed two independent GSH assays in the absence or presence of buthionine sulfoximine, which inhibits gamma-glutamylcysteine synthetase (also known as glutamate-cysteine ligase), the rate-limiting enzyme in GSH
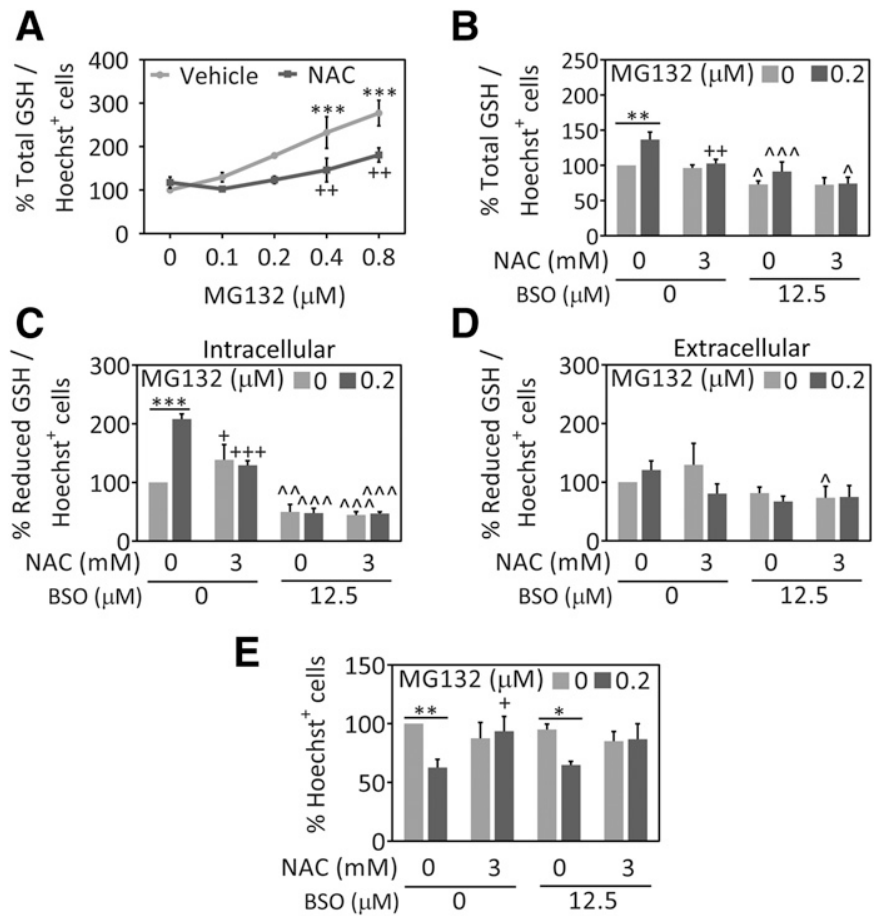

Fig. 2. NAC protects astrocytes against proteotoxicity independent of GSH synthesis. Primary cortical astrocytes were treated with the indicated MG132 concentrations or dimethylsulfoxide in the presence of NAC (3 mM) or the equivalent v/v of vehicle $\left(\mathrm{H}_{2} \mathrm{O}\right)$. (A) Total GSH levels were measured 48 hours later by a fluorescent In-Cell Western assay. Total GSH levels are expressed as a function of the number of Hoechst ${ }^{+}$cell numbers to control for differences in cell density. (B) Total GSH levels as a function of the number of Hoechst ${ }^{+}$nuclei in the absence and presence of GSH synthesis inhibitor, buthionine sulfoximine (BSO). Intracellular (C) and extracellular (D) reduced GSH levels were measured by the luminescent GSH-Glo assay in the absence or presence of BSO and expressed as a function of cell numbers. (E) Blinded counts of the number of Hoechst ${ }^{+}$ nuclei 48 hours after treatment with MG132, NAC, and BSO or their respective vehicles. Shown are the mean and S.E.M. values of $3-5$ independent experiments. $* P \leq 0.05$; $* * P \leq 0.01$; $* * * P \leq 0.001$ versus $0 \mu \mathrm{M}$ MG132; ${ }^{+} P \leq 0.05 ;{ }^{++} P \leq 0.01 ;{ }^{+++} P \leq 0.01$ versus $0 \mathrm{mM} \mathrm{NAC} ;{ }^{\wedge} P \leq$ $0.05 ; \wedge \wedge P \leq 0.01 ;{ }^{\wedge} \wedge \wedge P \leq 0.001$ versus $0 \mu \mathrm{M}$ BSO, two- or three-way analysis of variance followed by the Bonferroni post hoc correction. synthesis (Griffith, 1982) (Fig. 2, B and C). Data obtained with the GSH-Glo assay confirmed that MG132 increased the levels of reduced GSH. Furthermore, NAC raised intracellular levels of reduced GSH in the absence of MG132 but decreased levels of reduced GSH in MG132-treated cells (Fig. 2C). Extracellular reduced GSH levels were unaffected by NAC or MG132 (Fig. 2D). While these data were unexpected, they suggest that MG132 elicits compensatory increases in GSH defenses and that NAC reduces the need for this stress response by blunting MG132 toxicity. In other words, the data support the hypothesis that NAC decreased MG132 toxicity independent of GSH synthesis. To test this hypothesis directly, we treated astrocytes with buthionine sulfoximine to decrease total and reduced GSH levels inside the cells and measured viability 48 hours later (Fig. 2E). Buthionine sulfoximine exerted no impact on the protection of viability afforded by NAC. These data support the view that NAC protects astrocytes from proteotoxicity in a GSH-independent manner.

MG132 Toxicity Is Ameliorated in the Presence of L-Cysteine or D-Cysteine. NAC is thought to boost GSH levels indirectly by increasing the pool of available cysteine (Zhou et al., 2015; Martínez-Banaclocha, 2016). Naturally occurring L-cysteine can be converted directly into GSH, whereas its unnatural enantiomer D-cysteine cannot. However, both forms contain a free sulfhydryl group and are protective (Corcoran and Wong, 1986; Masukawa et al., 1989; Karg et al., 1990; Huang et al., 1998; Requejo et al., 2010). We treated cells with MG132 in the absence or presence of L-cysteine or D-cysteine to test whether these compounds would protect astrocytes equally well against MG132 toxicity, despite exhibiting differences in direct conversion to GSH (Masukawa et al., 1989). As expected, MG132 toxicity was abolished to the same degree in the presence of either L-cysteine or D-cysteine (Fig. 3, A and B). These findings are consistent with direct protection by free sulfhydryl groups at millimolar concentrations without recourse to GSH-mediated protection. Given the lack of effect of buthionine sulfoximine on NACmediated protection, these results collectively support the view that the protective effects of NAC are GSH independent in astrocytes.

In contrast to NAC, L-cysteine, and D-cysteine, NMC lacks a free thiol group. To examine whether the thiol functional group is instrumental in eliciting protective effects against MG132, we treated astrocytes with NMC or vehicle in the absence or presence of MG132 (Fig. 3C). As expected, NMC failed to protect against MG132 toxicity. We tested nine concentrations of NMC and performed a second viability assay with the DRAQ5 stain for nuclei to reduce the risk of a type II error or false negative (Fig. 3, C and D). The results of both viability assays were in agreement that the thiol-lacking molecule NMC failed to confer protection against MG132.

Impact of NAC on Heat Shock Protein Levels in Astrocytes. In a previous study, we found that Hsp70 levels following proteasome inhibition were higher in NAC-treated cells (Jiang et al., 2013). However, in astrocytes, NAC attenuated an MG132-dependent rise in Hsp70 (Fig. 4A). Hsc70 levels were similarly increased by MG132 and NAC also abolished this effect (Fig. 4B). In our previous study with the N2a neuronal cells, we found that heme oxygenase 1 [(HO1), also known as heat shock protein 32] levels exhibited a trend toward an increase in NAC-treated cells after MG132 

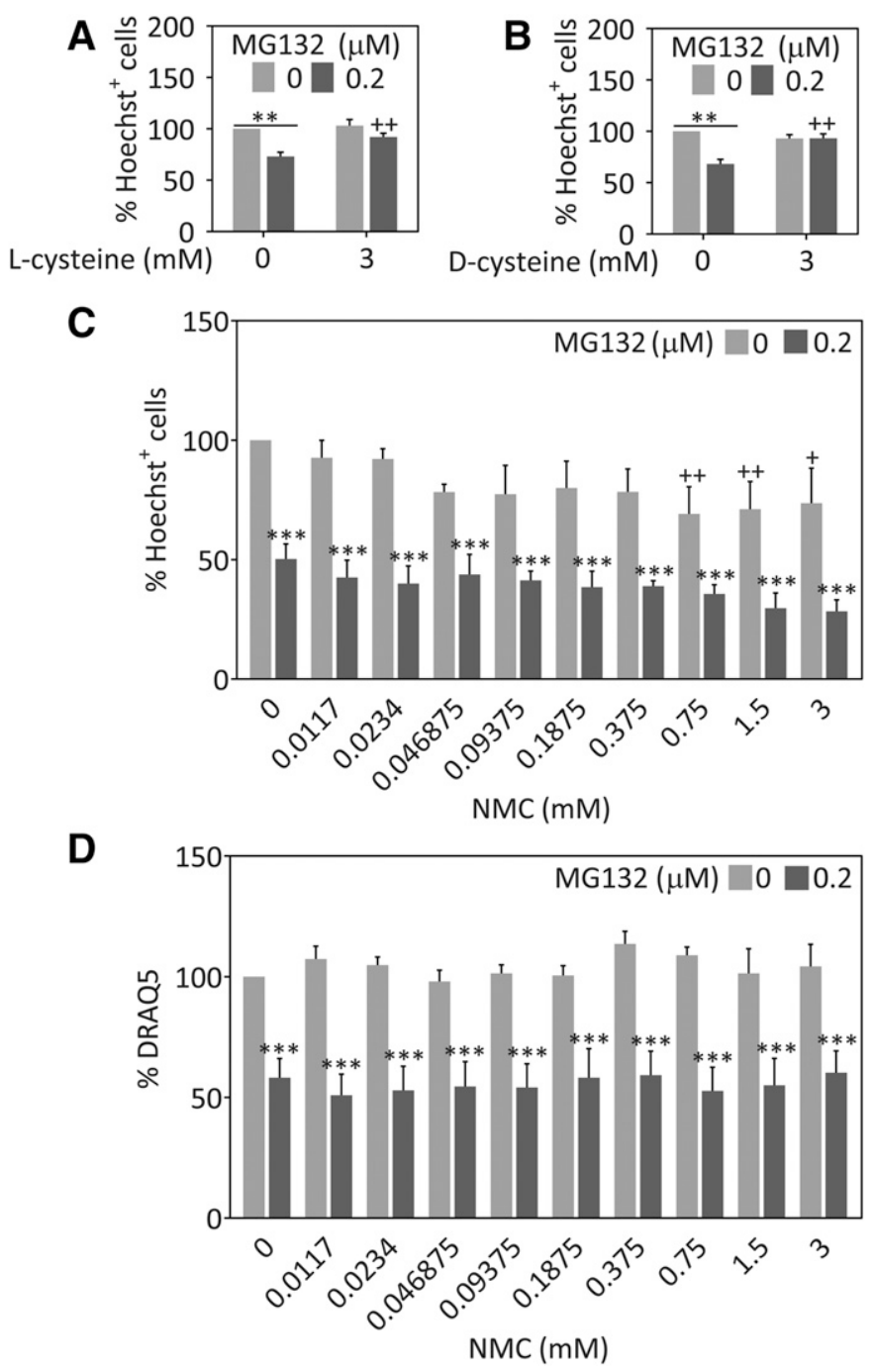

Fig. 3. L-cysteine and D-cysteine, but not NMC protect astrocytes against proteotoxicity. Primary cortical astrocytes were treated with MG132 or vehicle and with L-cysteine (A), D-cysteine (B), NMC (C), or vehicle. Viability was measured 48 hours later by blinded counts of the number of $\mathrm{Hoechst}^{+}$nuclei (A-C) or DRAQ5 nuclear staining (D). **P $\leq 0.01$; *** $P \leq 0.001$ versus $0 \mu \mathrm{M}$ MG132; ${ }^{+} P \leq 0.05 ;{ }^{++} P \leq 0.01 ;{ }^{+++} P \leq 0.001$ versus $0 \mathrm{mM}$ D-cysteine, L-cysteine, or NMC, two-way analysis of variance followed by the Bonferroni post hoc test.

exposure (Jiang et al., 2013). Therefore, we also examined HO1 and other heat shock protein levels. As shown in Fig. 4C, MG132 increased HO1 levels in astrocytes and this rise was attenuated by NAC. Heat shock protein 25 levels were also raised by MG132, but this effect was not modulated by NAC (Fig. 4D). However, the phosphorylation of heat shock protein 25 in response to MG132-mediated toxicity was significantly attenuated by NAC (Fig. 4, E and F). Similar to the other heat shock proteins, heat shock proteins 40 and 90 were also augmented by MG132 and NAC inhibited this response (Fig. 4, $\mathrm{G}$ and $\mathrm{H}$ ). Thus, the patterns we observed were remarkably consistent in that NAC appeared to reduce the need for defensive heat shock protein induction in astrocytes.

The data presented here consistently suggest that heat shock protein levels are reduced by NAC in astrocytes. However, Hsp70 and Hsc70 might still be less damaged and more active in NAC-treated cells, and they might work in parallel with NAC to temper proteotoxic stress. To investigate these hypotheses, we inhibited the ATPase activity of Hsp70/Hsc70 with a compound that binds to the chaperone's active site, VER155008 (Massey et al., 2010; Saykally et al., 2012; Chatterjee et al., 2013; Schlecht et al., 2013). We found that treatment with VER155008 prevented NAC-mediated protection (Fig. 5A). As in neuroblastoma cells, VER155008 was also significantly toxic and reduced basal viability in astrocytes (Jiang et al., 2013). Because of the basal toxicity of VER155008, we also expressed astrocyte viability as a percentage of each $0 \mu \mathrm{M}$ MG132 group to facilitate rigorous statistical comparisons of the impact of NAC versus vehicle (Fig. 5B). This alternative illustration of the data clearly reveals that MG132 was equally toxic in the absence or presence of NAC when VER155008 was applied. These findings suggest that astrocytes treated with NAC rely on Hsp70/Hsc70 activity to battle proteotoxicity.

All pharmacological inhibitors can exert nonspecific effects (Budina-Kolomets et al., 2014). Therefore, it is advisable to use multiple inhibitors with distinct mechanisms of action since it would be unlikely that independent classes of inhibitors exert precisely the same off-target effects. Thus, we also treated astrocytes with PES and MAL3-101, to verify whether Hsp70/Hsc70 activity acts along with NAC to offset proteotoxic stress. PES inhibits the interactions of Hsp70/Hsc70 with several cochaperones and substrate proteins, such as CHIP, BAG-1, and heat shock protein 40 (Leu et al., 2009, 2011; Granato et al., 2013; Kondoh and Osada, 2013). MAL3-101 specifically interferes with Hsp70/Hsc70 chaperone activity by blocking heat shock protein 40-stimulated ATP hydrolysis (Fewell et al., 2004; Braunstein et al., 2011; Huryn et al., 2011; Hatic et al., 2012; Kilpatrick et al., 2013; Adam et al., 2014). Similar to VER155008, PES and MAL3101 also attenuated the protection afforded by NAC (Fig. 5, $\mathrm{C}-\mathrm{E}$ ). These findings are consistent with our previous study on N2a cells (Jiang et al., 2013), and suggest again that NAC protects primary cortical astrocytes through a process that benefits from $\mathrm{Hsp} 70 / \mathrm{Hsc70}$ function.

MG132 Triggers a Rise in the Level of Ubiquitinated Proteins and NAC Completely Abolishes this Response. In response to proteotoxicity and protein denaturation, ubiquitin is attached to misfolded proteins to tag them for degradation by the proteasome. When proteasome inhibitors are applied, ubiquitinated protein levels accumulate because the tagged proteins can no longer be degraded. Heat shock proteins such as Hsp70 are known to refold misfolded proteins and enhance ubiquitin-mediated degradation of damaged proteins by the proteasome (Gusarova et al., 2001; Zhang et al., 2001; Bailey et al., 2002; Adachi et al., 2003; Tsai et al., 2003; Kalia et al., 2004, 2010; Lanneau et al., 2010; Needham et al., 2011). Thus, if NAC also blunts the accumulation of ubiquitinated protein levels in the cell, it might be mitigating loss of protein quality control with the help of chaperones, as suggested previously. In support of this hypothesis, NAC abolished the rise in ubiquitinated proteins elicited in response to MG132 (Fig. 6A). As expected, NMC failed to exert a similar effect on ubiquitinated proteins (Fig. 6B). Next, we examined the impact of MG132 and NAC on the proteasome regulators PA28 $\alpha$ and PA700. If NAC increased the expression of these proteasome subunits, this might also explain why it abolished the rise in ubiquitinated proteins. However, the expression of neither PA2 $8 \alpha$ nor the $42 \& 46 \mathrm{kDa}$ subunits of the PA700 particle was altered upon NAC addition (Fig. 6, C-E). 
A

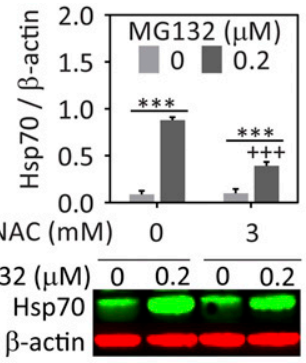

E

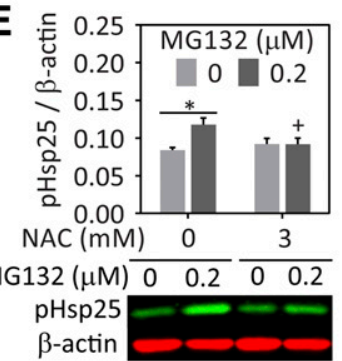

B
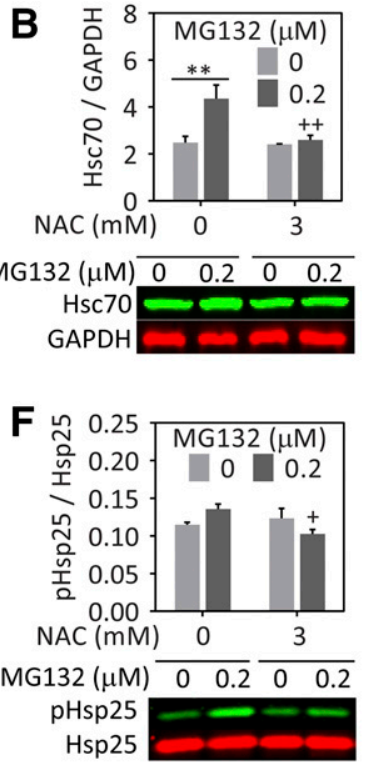
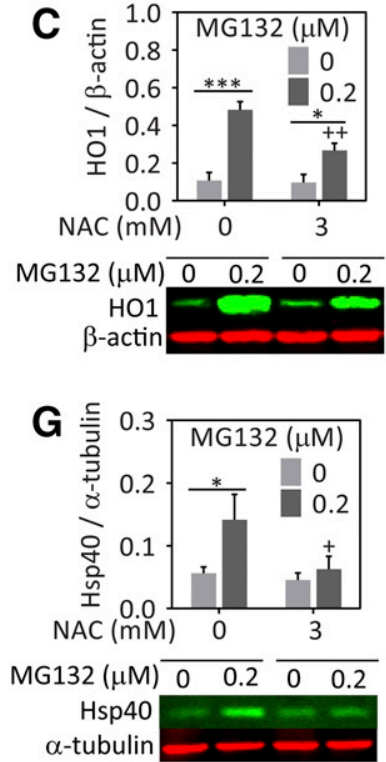

D
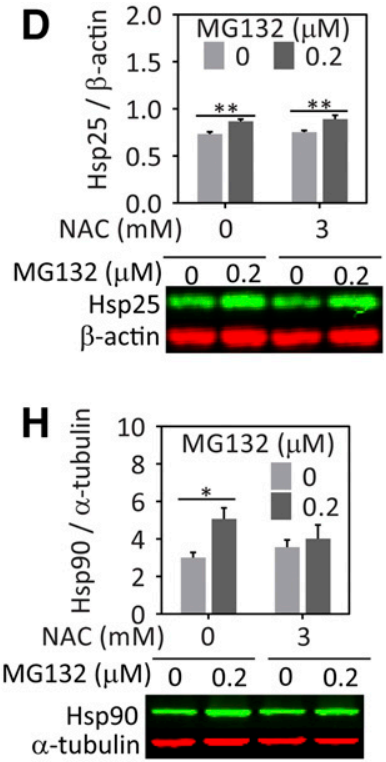

Fig. 4. NAC attenuates the MG132-induced increase in heat shock proteins in astrocytes. Primary cortical astrocytes were treated with MG132 or vehicle in the presence of NAC or vehicle. Lysates were collected 24 hours later and heat shock proteins were measured by western blot analyses. Representative western blot images are included below each graph. (A) Hsp70, (B) Hsc70, (C) HO1 (or heat shock protein 32), (D) heat shock protein 25 (Hsp25), (E and F) phosphorylated Hsp25, (G) heat shock protein 40 (Hsp40), and (H) heat shock protein 90 (Hsp90). Protein levels are expressed as a function of the loading controls $\beta$-actin, glyceraldehyde-3-phosphate dehydrogenase (GAPDH), or $\alpha$-tubulin, depending on the species of the antibody for the protein of interest and its molecular weight. Infrared images are pseudocolored green and red. Shown are the mean and S.E.M. values of $3-5$ independent experiments. ${ }^{*} P \leq 0.05 ;{ }^{* *} P \leq 0.01 ; * * * P \leq 0.001$ versus $0 \mu \mathrm{M}$ MG132; ${ }^{+} P \leq 0.05 ;{ }^{++} P \leq 0.01 ;{ }^{+++} P \leq 0.01$ versus 0 mM NAC, two-way analysis of variance followed by the Bonferroni post hoc test.

\section{Discussion}

As investigations have shifted away from the traditionally neurocentric view of neurologic disorders, it has become increasingly evident that astrocytes are severely impacted in many of these conditions (Charron et al., 2014; Phatnani and Maniatis, 2015). It is therefore important to identify therapies that protect this cell type in addition to neurons. A few studies have already suggested that NAC can affect astrocytes in experimental models of disease. For example, NAC raises GSH levels and reduces ischemia-related damage in astrocytes (Gabryel et al., 2005). NAC also decreases the stress-induced rise in HO1 within astrocytes and reduces lesion volume after traumatic brain injury (Yi and Hazell, 2005). Furthermore, NAC inhibits the astrocytic increase in nitrite accumulation following inflammatory stimuli such as lipopolysaccharides and cytokines (Pahan et al., 1998). In studies of pain, NAC elicits analgesia in vivo and this is thought to occur through activation of system $\mathrm{x}_{\mathrm{c}}^{-}$within astrocytes (Bernabucci et al., 2012). NAC also reduces oxidative stress in cultured astrocytes exposed to serum deprivation (Messina et al., 2008). The present study adds to this body of work by showing for the first time that NAC reduces proteasome inhibitor-induced astrocyte cell death without directly interfering with the ability of MG132 to suppress proteasome activity. These observations suggest that NAC does not merely reduce the efficacy of the toxicant but protects astrocytes against the subsequent loss of protein homeostasis. Consistent with this view, NAC completely abolished the MG132-induced rise in ubiquitinated proteins, suggesting an improvement in protein quality control despite loss of proteasome function. Inhibition of Hsp70/Hsc70 activity, but not of GSH synthesis, abolished the NAC-mediated protection, suggesting that chaperones are better able to control protein homeostasis in NAC-treated cells.
Proteasome inhibition prevents the degradation of oxidized and misfolded proteins and increases the levels of reactive oxygen species (Ding et al., 2006; Dasuri et al., 2011). For example, previous work has shown that MG132 treatment increases markers of oxidative stress (Alexandrova et al., 2008; Maharjan et al., 2014). These effects of proteasome inhibitors may have led to the compensatory increase in GSH that we observed in MG132-treated astrocytes. NAC may prevent oxidative damage directly by increasing the pool of free thiols, indirectly through biochemical incorporation of cysteine into GSH, or by a yet unidentified mechanism. In the present study, inhibition of GSH synthesis did not abolish the protection of astrocytes by NAC, supporting the view that not all actions of NAC are mediated through GSH repletion. Instead, NAC prevented the compensatory increase in GSH in response to MG132. Similarly, previous reports have demonstrated MG132-induced upregulation of GSH metabolism genes (Yu et al., 2010) and an alleviation of stressinduced increases in GSH with NAC application (Tchantchou et al., 2005). Accordingly, other investigators have reported that NAC is able to provide protection and scavenge free radicals independent of GSH synthesis (Aruoma et al., 1989; Yan et al., 1995; Steenvoorden and Beijersburgen van Henegouwen, 1998; Wispriyono et al., 1998; Han et al., 2010).

System $\mathrm{x}_{\mathrm{c}}^{-}$and alanine serine cysteine transporter 1 increase the intracellular pool of L-cysteine and D-cysteine (Fukasawa et al., 2000; Bridges et al., 2012). Cysteines are incorporated into evolutionarily conserved sites on proteins, where they can mitigate oxidative attack (Requejo et al., 2010; Poole, 2015). NAC, L-cysteine, and D-cysteine contain a free sulfhydryl group, which imparts these molecules with 

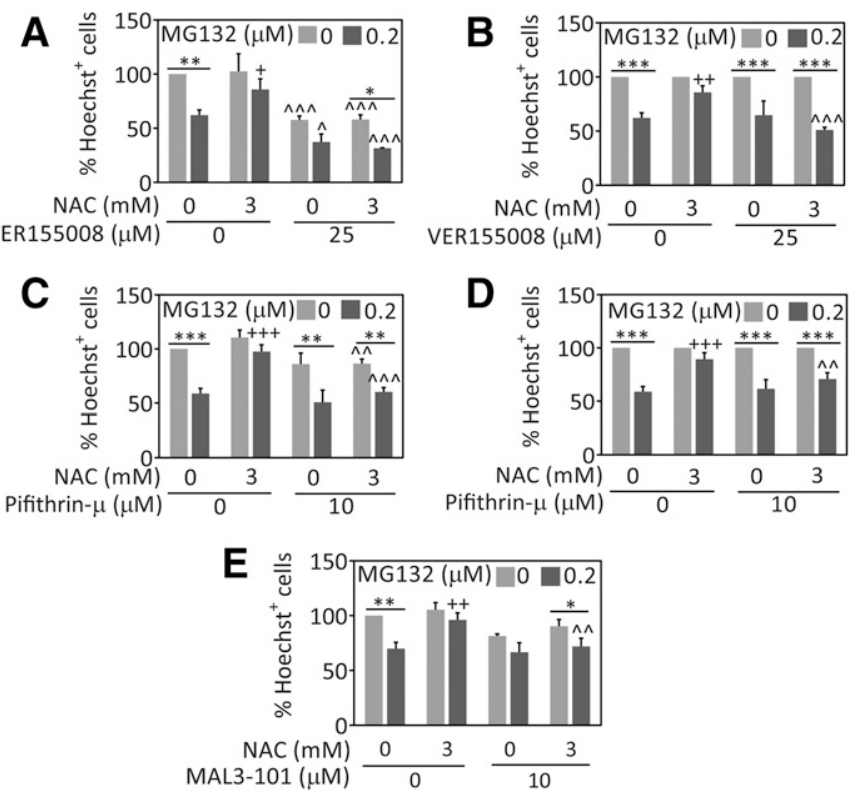

Fig. 5. Loss of Hsp70/Hsc70 activity abolishes NAC-mediated protection in astrocytes. Primary cortical astrocytes were treated with MG132 or vehicle, NAC or vehicle, and the Hsp70/Hsc70 inhibitors VER155008 (A and B), pifithrin- $\mu$ (C and D), MAL3-101 (E), or vehicle. Cell viability was measured 48 hours later by blinded counts of Hoechst-stained nuclei. VER155008 and pifithrin- $\mu$ led to significant loss of basal viability. Thus, data in (A and $\mathrm{C}$ ) are expressed as a percentage of the $0 \mu \mathrm{M}$ MG132 group in (B and D), respectively, to account for the basal viability loss. Shown are the mean and S.E.M. values of $3-5$ independent experiments. $* P \leq 0.05$, ${ }^{* *} P \leq 0.01,{ }^{* * *} P \leq 0.001$ versus $0 \mu \mathrm{M}$ MG132; ${ }^{+} P \leq 0.05,{ }^{++} P \leq 0.01$, ${ }^{+++} P \leq 0.001$ versus $0 \mathrm{mM} \mathrm{NAC} ;{ }^{\wedge} P \leq 0.05, \wedge \wedge P \leq 0.01, \wedge \wedge \wedge P \leq 0.001$ versus $0 \mu \mathrm{M}$ VER155008, pifithrin- $\mu$, or MAL3-101, three-way ANOVA followed by the Bonferroni post hoc correction.

nucleophilic and antioxidant properties and the capacity to form disulfide bonds independent of GSH (Aruoma et al., 1989; Requejo et al., 2010; Poole, 2015). In addition to NACmediated glioprotective effects, we observed that L-cysteine and D-cysteine robustly protect astrocytes against MG132, perhaps through a GSH-independent mechanism. D-cysteine can protect against cyanide toxicity and detoxify acetaminophen, but is ineffective at replenishing GSH stores compared with L-cysteine (Masukawa et al., 1989; Huang et al., 1998; Berkeley et al., 2003; Friedman and Levin, 2012). This protective ability is not shared with the disfulfide D-cystine, suggesting that the sulfhydryl group of D-cysteine might mediate detoxification. NMC lacks a thiol group and failed to protect astrocytes against MG132 toxicity or to mitigate the increase in ubiquitinated proteins. Hsp70 contains a reactive cysteine group (Cys306) that is oxidized by redox-active compounds such as methylene blue, and this oxidation inhibits Hsp70 ATPase activity (Miyata et al., 2012). In addition, the endoplasmic reticulum Hsp70 protein, BiP, has a cysteine group that is oxidized to form a sulfenic acid moiety, also resulting in loss of ATPase activity (Wang et al., 2014). As proteasome inhibition is known to raise oxidative stress levels, Hsp70 and Hsc70 may not function well under these conditions (Adachi et al., 2009). Thus, future studies are warranted to determine whether NAC can prevent MG132-induced oxidation of Hsp70 and preserve its ATPase function, which would be consistent with the ablation of its protective abilities with all three Hsp70 inhibitors.

NAC has been shown to protect primary neurons and neuroblastoma cells against proteasome inhibition ( $\mathrm{Li}$ et al., 2012; Jiang et al., 2013; Posimo et al., 2013; Heinemann et al., 2016). In contrast to our previous studies on neuroblastoma cells (Jiang et al., 2013), NAC did not preserve Hsp70 protein levels in primary astrocytes. Previous studies have examined the impact of NAC on Hsp70, and most are in agreement that cellular stress leads to an increase in Hsp70 and that this is reversed by NAC, similar to what we observed in the astrocyte model (Chen et al., 1990; Grogan et al., 2013, 2014; Hensen et al., 2013; Hou et al., 2013; Bianchi et al., 2014). Furthermore, some studies have shown that inhibition of Hsp70 activity by PES results in a compensatory increase in Hsp70 protein levels and this response is also attenuated by NAC (Zeng et al., 2014). Thus, stressed astrocytes may need less

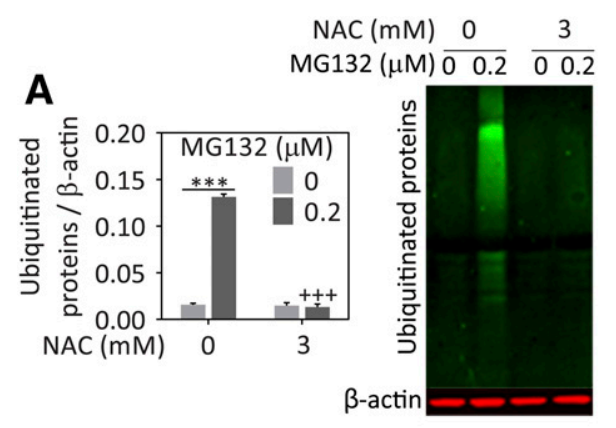

\section{B}

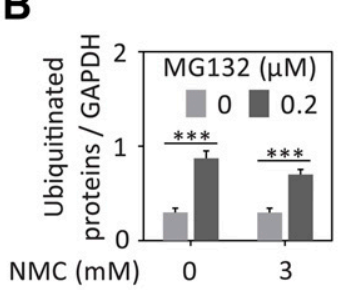

$\mathrm{NMC}(\mathrm{mM}) \quad 0 \quad 3$ MG132 $(\mu \mathrm{M}) \overline{00.2} \overline{00.2}$

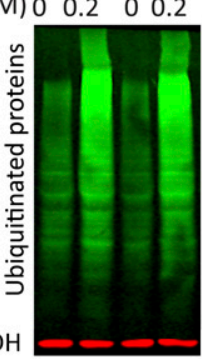

E

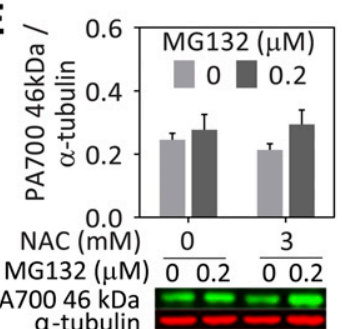

Fig. 6. NAC but not NMC attenuates the accrual of ubiquitinated proteins after proteasome inhibition. Primary cortical astrocytes were treated with MG132 or vehicle and NAC (A), NMC (B), or vehicle. Lysates were collected 24 hours later and ubiquitinated proteins were assessed by western immunoblotting. Representative images are shown adjacent to the quantification. The NAC-treated lysates were further probed for (C) PA28 $\alpha$, (D) PA700 $42 \mathrm{kDa}$ subunit, and (E) PA700 $46 \mathrm{kDa}$ subunit. All proteins are expressed as a fraction of $\beta$-actin, glyceraldehyde-3-phosphate dehydrogenase (GAPDH), or $\alpha$-tubulin levels. Note that the PA700 antibody binds both 42 and $46 \mathrm{kDa}$ PA700 proteins and that the images are therefore from the same western blot and have the same loading control, $\alpha$-tubulin. Infrared images are pseudocolored green and red. Shown are the mean and S.E. $M$. values of $3-5$ independent experiments. $* P \leq 0.05 ; * * * P \leq 0.001$ versus $0 \mu \mathrm{M}$ MG132; ${ }^{+++} P \leq 0.001$ versus $0 \mathrm{mM}$ NAC, two-way analysis of variance followed by the Bonferroni post hoc test. 
Hsp70 in the presence of NAC because it reduces those stimuli that induce Hsp70, including cysteine oxidation and protein denaturation. Consistent with this view, we observed a decrease in ubiquitinated proteins in response to NAC, suggesting a reduction in protein denaturation. However, as argued previously, Hsp70 molecules may function better in a less oxidative environment in the presence of NAC, which would reduce the levels of ubiquitinated proteins, protect against cell death, and diminish the need for Hsp70 protein induction. Thus, NAC might work in parallel with Hsp70 chaperone activity, such that only the combination of both is sufficient to elicit a robust protection against MG132 in our model.

One caveat of the present study is that we were not able to measure Hsp70 and Hsc70 activity in cellular lysates because the ATPase activity of these proteins would be masked by the presence of many other ATPases. Another important limitation is that pharmacological inhibitors often exert nonspecific effects. Although some studies have suggested that these inhibitors work on molecules other than Hsp70/Hsc70, some of the effects previously deemed nonspecific may actually be through Hsp70/Hsc70 inhibition. For example, both PES and VER155008 inhibit autophagy (Leu et al., 2009; BudinaKolomets et al., 2014), but this might be mediated by loss of Hsc70 activity because Hsc70 helps escort proteins with a KFERQ motif to the lysosome for degradation by chaperonemediated autophagy (Shin et al., 2005; Arias and Cuervo, 2011). Furthermore, both PES and VER155008 reduce the levels of heat shock protein 90 client proteins, also perhaps by inhibiting Hsp70 chaperone action (Massey et al., 2010; Leu et al., 2011; Budina-Kolomets et al., 2014). PES is thought to prevent p53 accumulation at the mitochondrion, thereby suppressing apoptosis (Strom et al., 2006; Leu and George, 2007). However, this effect could not explain the present findings because PES increased cell death in our model. In all of our experiments, we employed relatively low concentrations of the inhibitors, which reduced the risk of off-target effects. The use of low concentrations can be of concern if no inhibitory effect is observed, increasing the risk of a type II error or false negative result. However, all the inhibitors were effective in our study, including buthionine sulfoximine, which lowered GSH levels as expected.

To further address the concern about nonspecific effects, we used three structurally and mechanistically diverse inhibitors of Hsp70/Hsc70. Given their distinct mechanisms of action, it would be highly unlikely that all inhibitors have the same effects on NAC-mediated protection through coincident offtarget effects. It is more likely that they exert similar effects on NAC-mediated protection through the shared mechanism of action/inhibition of Hsp70 function. Nevertheless, we cannot completely rule out off-target effects, and knockdown or knockout of Hsp70 or Hsc70 in future studies would help confirm the inhibitor data. On the other hand, there are many members of the Hsp70 gene family that may compensate against loss of one member, thereby confounding the interpretation of RNA interference or gene knockout studies. The strength of our experimental design is that we employed pan-Hsp70 inhibitors to mitigate this concern.

As mentioned previously, the present study confirms and extends earlier works showing that NAC is protective in experimental models of disease (for some examples, see Pocernich et al., 2000; Farr et al., 2003; Tucker et al., 2006; Clark et al., 2010). The present study extends the protective effects of NAC to astrocytes under conditions of severe proteotoxic stress and demonstrates that NAC may exert effects other than as a GSH precursor. Currently, there are no safe ways of boosting heat shock protein function in patients with neurodegeneration, but NAC may fulfill this important role.

\section{Acknowledgments}

The authors are grateful to Mary Caruso, Deborah Willson, and Jackie Farrer for excellent administrative support and to Denise Butler-Bucilli and Christine Close for outstanding animal care.

\section{Authorship Contributions}

Participated in research design: Flaherty, Brodsky, R. K. Leak. Conducted experiments: Gleixner, Hutchison, Sannino, Bhatia,

L. C. Leak.

Contributed new reagents or analytic tools: Flaherty, Wipf.

Performed data analysis: Gleixner, Hutchison, Sannino, Bhatia,

L. C. Leak.

Wrote or contributed to the writing of the manuscript: Gleixner, Sannino, Wipf, Brodsky, R. K. Leak.

\section{References}

Adachi H, Katsuno M, Minamiyama M, Sang C, Pagoulatos G, Angelidis C, Kusakabe M, Yoshiki A, Kobayashi Y, Doyu M, et al. (2003) Heat shock protein 70 chaperone overexpression ameliorates phenotypes of the spinal and bulbar muscular atrophy transgenic mouse model by reducing nuclear-localized mutant androgen receptor protein. J Neurosci 23:2203-2211.

Adachi M, Liu Y, Fujii K, Calderwood SK, Nakai A, Imai K, and Shinomura Y (2009) Oxidative stress impairs the heat stress response and delays unfolded protein recovery. PLoS One 4:e7719.

Adair JC, Knoefel JE, and Morgan N (2001) Controlled trial of $N$-acetylcysteine for patients with probable Alzheimer's disease. Neurology 57:1515-1517.

Adam C, Baeurle A, Brodsky JL, Wipf P, Schrama D, Becker JC, and Houben R (2014) The HSP70 modulator MAL3-101 inhibits Merkel cell carcinoma. PLoS One 9:e92041.

Akiyama H, Mori H, Saido T, Kondo H, Ikeda K, and McGeer PL (1999) Occurrence of the diffuse amyloid beta-protein (Abeta) deposits with numerous Abeta-containing glial cells in the cerebral cortex of patients with Alzheimer's disease. Glia 25: 324-331.

Akiyama H, Schwab C, Kondo H, Mori H, Kametani F, Ikeda K, and McGeer PL (1996) Granules in glial cells of patients with Alzheimer's disease are immunopositive for C-terminal sequences of beta-amyloid protein. Neurosci Lett 206 : $169-172$

Alexandrova A, Petrov L, Georgieva A, Kirkova M, and Kukan M (2008) Effects of proteasome inhibitor, MG132, on proteasome activity and oxidative status of rat liver. Cell Biochem Funct 26:392-398.

Allen NJ and Barres BA (2009) Neuroscience: glia-more than just brain glue. $\mathrm{Na}$ ture 457:675-677.

Angot E, Steiner JA, Hansen C, Li JY, and Brundin P (2010) Are synucleinopathies prion-like disorders? Lancet Neurol 9:1128-1138.

Arias E and Cuervo AM (2011) Chaperone-mediated autophagy in protein quality control. Curr Opin Cell Biol 23:184-189.

Aruoma OI, Halliwell B, Hoey BM, and Butler J (1989) The antioxidant action of $N$ acetylcysteine: its reaction with hydrogen peroxide, hydroxyl radical, superoxide, and hypochlorous acid. Free Radic Biol Med 6:593-597.

Bailey CK, Andriola IF, Kampinga HH, and Merry DE (2002) Molecular chaperones enhance the degradation of expanded polyglutamine repeat androgen receptor in a cellular model of spinal and bulbar muscular atrophy. Hum Mol Genet 11:515-523.

Balaburski GM, Leu JI, Beeharry N, Hayik S, Andrake MD, Zhang G, Herlyn M, Villanueva J, Dunbrack RL, Jr, Yen T, et al. (2013) A modified HSP70 inhibitor shows broad activity as an anticancer agent. Mol Cancer Res 11:219-229.

Bentea E, Verbruggen L, and Massie A (2017) The proteasome inhibition model of Parkinson's disease. J Parkinsons Dis 7:31-63.

Berkeley LI, Cohen JF, Crankshaw DL, Shirota FN, and Nagasawa HT (2003) Hepatoprotection by L-cysteine-glutathione mixed disulfide, a sulfhydryl-modified prodrug of glutathione. J Biochem Mol Toxicol 17:95-97.

Bernabucci M, Notartomaso S, Zappulla C, Fazio F, Cannella M, Motolese M, Battaglia G, Bruno V, Gradini R, and Nicoletti F (2012) N-Acetyl-cysteine causes analgesia by reinforcing the endogenous activation of type- 2 metabotropic glutamate receptors. Mol Pain 8:77.

Bianchi A, Moulin D, Hupont S, Koufany M, Netter P, Reboul P, and Jouzeau JY (2014) Oxidative stress-induced expression of HSP70 contributes to the inhibitory effect of 15d-PGJ2 on inducible prostaglandin pathway in chondrocytes. Free Radic Biol Med 76:114-126.

Braak H and Braak E (1995) Staging of Alzheimer's disease-related neurofibrillary changes. Neurobiol Aging 16:271-278 [discussion 278-284].

Braak H, Del Tredici K, Rüb U, de Vos RA, Jansen Steur EN, and Braak E (2003) Staging of brain pathology related to sporadic Parkinson's disease. Neurobiol Aging 24:197-211. 
Braak H, Sastre M, and Del Tredici K (2007) Development of $\alpha$-synuclein immunoreactive astrocytes in the forebrain parallels stages of intraneuronal pathology in sporadic Parkinson's disease. Acta Neuropathol 114:231-241.

Braunstein MJ, Scott SS, Scott CM, Behrman S, Walter P, Wipf P, Coplan JD, Chrico W, Joseph D, Brodsky JL, et al. (2011) Antimyeloma effects of the heat shock protein 70 molecular chaperone inhibitor MAL3-101. J Oncol 2011:232037.

Brera B, Serrano A, and de Ceballos ML (2000) $\beta$-Amyloid peptides are cytotoxic to astrocytes in culture: a role for oxidative stress. Neurobiol Dis 7:395-405.

Bridges RJ, Natale NR, and Patel SA (2012) System $\mathrm{x}_{\mathrm{c}}^{-}$cystine/glutamate antiporter: an update on molecular pharmacology and roles within the CNS. Br J Pharmacol 165:20-34.

Brito MA, Rosa AI, Falcão AS, Fernandes A, Silva RF, Butterfield DA, and Brites D (2008) Unconjugated bilirubin differentially affects the redox status of neuronal and astroglial cells. Neurobiol Dis 29:30-40.

Budina-Kolomets A, Balaburski GM, Bondar A, Beeharry N, Yen T, and Murphy ME (2014) Comparison of the activity of three different HSP70 inhibitors on apoptosis, cell cycle arrest, autophagy inhibition, and HSP90 inhibition. Cancer Biol Ther 15: 194-199.

Charron G, Doudnikoff E, Canron MH, Li Q, Véga C, Marais S, Baufreton J, Vital A, Oliet SH, and Bezard E (2014) Astrocytosis in parkinsonism: considering tripartite striatal synapses in physiopathology? Front Aging Neurosci 6:258.

Chatterjee M, Andrulis M, Stühmer T, Müller E, Hofmann C, Steinbrunn T, Heimberger T, Schraud H, Kressmann S, Einsele H, et al. (2013) The PI3K/Akt signaling pathway regulates the expression of Hsp70, which critically contributes to Hsp90chaperone function and tumor cell survival in multiple myeloma. Haematologica 98:1132-1141.

Chen CJ, Wu HY, Chuang YC, Chang AS, Luh KT, Chao HH, Chen KY, Chen SG, Lai GM, Huang HH, et al. (1990) Epidemiologic characteristics and multiple risk factors of lung cancer in Taiwan. Anticancer Res 10:971-976.

Chen L, Thiruchelvam MJ, Madura K, and Richfield EK (2006) Proteasome dysfunction in aged human $\alpha$-synuclein transgenic mice. Neurobiol Dis 23:120-126.

Chen Q, Thorpe J, and Keller JN (2005) $\alpha$-Synuclein alters proteasome function, protein synthesis, and stationary phase viability. $J$ Biol Chem 280 30009-30017.

Cheng B, Anand P, Kuang A, Akhtar F, and Scofield VL (2016) N-acetylcysteine in combination with IGF-1 enhances neuroprotection against proteasome dysfunction-induced neurotoxicity in SH-SY5Y cells. Parkinsons Dis 2016: 6564212

Ciechanover A and Kwon YT (2017) Protein quality control by molecular chaperones in neurodegeneration. Front Neurosci 11:185.

Clark J, Clore EL, Zheng K, Adame A, Masliah E, and Simon DK (2010) Oral $\mathrm{N}$-acetyl-cysteine attenuates loss of dopaminergic terminals in $\alpha$-synuclein overexpressing mice. PLoS One $\mathbf{5}: \mathrm{e} 12333$.

Corcoran GB and Wong BK (1986) Role of glutathione in prevention of acetaminophen-induced hepatotoxicity by $N$-acetyl-L-cysteine in vivo: studies with $N$-acetyl-D-cysteine in mice. J Pharmacol Exp Ther 238:54-61.

Dabir DV, Trojanowski JQ, Richter-Landsberg C, Lee VM, and Forman MS (2004) Expression of the small heat-shock protein $\alpha \mathrm{B}$-crystallin in tauopathies with glial pathology. Am J Pathol 164:155-166.

Dasuri K, Zhang L, Ebenezer P, Fernandez-Kim SO, Bruce-Keller AJ, Szweda LI, and Keller JN (2011) Proteasome alterations during adipose differentiation and aging: links to impaired adipocyte differentiation and development of oxidative stress. Free Radic Biol Med 51:1727-1735.

de Ceballos ML, Brera B, and Fernández-Tomé MP (2001) $\beta$-Amyloid-induced cytotoxicity, peroxide generation and blockade of glutamate uptake in cultured astrocytes. Clin Chem Lab Med 39:317-318.

Dickson DW (2009) Neuropathology of non-Alzheimer degenerative disorders. Int $J$ Clin Exp Pathol 3:1-23.

Ding Q, Dimayuga E, and Keller JN (2006) Proteasome regulation of oxidative stress in aging and age-related diseases of the CNS. Antioxid Redox Signal 8:163-172.

Durrenberger PF, Filiou MD, Moran LB, Michael GJ, Novoselov S, Cheetham ME, Clark P, Pearce RK, and Graeber MB (2009) DnaJB6 is present in the core of Lewy bodies and is highly up-regulated in parkinsonian astrocytes. J Neurosci Res $\mathbf{8 7}$ $238-245$.

Duyckaerts C, Delatour B, and Potier MC (2009) Classification and basic pathology of Alzheimer disease. Acta Neuropathol 118:5-36.

Ebrahimi-Fakhari D, Cantuti-Castelvetri I, Fan Z, Rockenstein E, Masliah E, Hyman BT, McLean PJ, and Unni VK (2011) Distinct roles in vivo for the ubiquitin proteasome system and the autophagy-lysosomal pathway in the degradation of $\alpha$-synuclein. J Neurosci 31:14508-14520.

Emmanouilidou E, Melachroinou K, Roumeliotis T, Garbis SD, Ntzouni M, Margaritis LH, Stefanis L, and Vekrellis K (2010) Cell-produced $\alpha$-synuclein is secreted in a calcium-dependent manner by exosomes and impacts neuronal survival. $J$ Neurosci 30:6838-6851.

Farr SA, Poon HF, Dogrukol-Ak D, Drake J, Banks WA, Eyerman E, Butterfield DA and Morley JE (2003) The antioxidants $\alpha$-lipoic acid and $N$-acetylcysteine reverse memory impairment and brain oxidative stress in aged SAMP8 mice. $J$ Neurochem 84:1173-1183.

Fewell SW, Smith CM, Lyon MA, Dumitrescu TP, Wipf P, Day BW, and Brodsky JL (2004) Small molecule modulators of endogenous and co-chaperone-stimulated Hsp70 ATPase activity. J Biol Chem 279:51131-51140.

Fontaine SN, Martin MD, and Dickey CA (2016) Neurodegeneration and the heat shock protein 70 machinery: implications for therapeutic development. Curr Top Med Chem 16:2741-2752.

Fornai F, Lazzeri G, Bandettini Di Poggio A, Soldani P, De Blasi A, Nicoletti F, Ruggieri S, and Paparelli A (2006) Convergent roles of $\alpha$-synuclein, DA metabolism, and the ubiquitin-proteasome system in nigrostriatal toxicity. Ann N Y Acad Sci 1074:84-89.

Fornai F, Lenzi P, Gesi M, Ferrucci M, Lazzeri G, Busceti CL, Ruffoli R, Soldani P, Ruggieri S, Alessandri MG, et al. (2003) Fine structure and biochemical mechanisms underlying nigrostriatal inclusions and cell death after proteasome inhibition. J Neurosci 23:8955-8966.

Friedman M and Levin CE (2012) Nutritional and medicinal aspects of D-amino acids. Amino Acids 42:1553-1582.

Fukasawa Y, Segawa H, Kim JY, Chairoungdua A, Kim DK, Matsuo H, Cha SH, Endou H, and Kanai Y (2000) Identification and characterization of a $\mathrm{Na}^{+}$-independent neutral amino acid transporter that associates with the 4F2 heavy chain and exhibits substrate selectivity for small neutral D- and L-amino acids. $J$ Biol Chem 275:9690-9698.

Gabryel B, Toborek T, and Małecki A (2005) Immunosuppressive immunophilin ligands attenuate damage in cultured rat astrocytes depleted of glutathione and exposed to simulated ischemia in vitro: comparison with $\mathrm{N}$-acetylcysteine. Neurotoxicology 26:373-384.

Gleixner AM, Posimo JM, Pant DB, Henderson MP, and Leak RK (2016) Astrocytes surviving severe stress can still protect neighboring neurons from proteotoxic injury. Mol Neurobiol 53:4939-4960.

Granato M, Lacconi V, Peddis M, Lotti LV, Di Renzo L, Gonnella R, Santarelli R, Trivedi P, Frati L, D'Orazi G, et al. (2013) HSP70 inhibition by 2-phenylethynesulfonamide induces lysosomal cathepsin D release and immunogenic cell death in primary effusion lymphoma. Cell Death Dis 4:e730.

Griffith OW (1982) Mechanism of action, metabolism, and toxicity of buthionine sulfoximine and its higher homologs, potent inhibitors of glutathione synthesis. $J$ Biol Chem 257:13704-13712.

Grogan PT, Sarkaria JN, Timmermann BN, and Cohen MS (2014) Oxidative cytotoxic agent withaferin A resensitizes temozolomide-resistant glioblastomas via MGMT depletion and induces apoptosis through Akt/mTOR pathway inhibitory modulation. Invest New Drugs 32:604-617.

Grogan PT, Sleder KD, Samadi AK, Zhang H, Timmermann BN, and Cohen MS (2013) Cytotoxicity of withaferin A in glioblastomas involves induction of an oxidative stress-mediated heat shock response while altering Akt/mTOR and MAPK signaling pathways. Invest New Drugs 31:545-557.

Gusarova V, Caplan AJ, Brodsky JL, and Fisher EA (2001) Apoprotein B degradation is promoted by the molecular chaperones hsp90 and hsp70. J Biol Chem 276: 24891-24900.

Halasi M, Wang M, Chavan TS, Gaponenko V, Hay N, and Gartel AL (2013) ROS inhibitor $N$-acetyl-L-cysteine antagonizes the activity of proteasome inhibitors. Biochem J 454:201-208.

Han YH, Moon HJ, You BR, Kim SZ, Kim SH, and Park WH (2010) The effects of $\mathrm{N}$-acetyl cysteine on the MG132 proteasome inhibitor-treated lung cancer cells in relation to cell growth, reactive oxygen species and glutathione. Int J Mol Med 25: $657-662$

Hatic H, Kane MJ, Saykally JN, and Citron BA (2012) Modulation of transcription factor Nrf2 in an in vitro model of traumatic brain injury. $J$ Neurotrauma 29 1188-1196.

Heinemann SD, Posimo JM, Mason DM, Hutchison DF, and Leak RK (2016) Synergistic stress exacerbation in hippocampal neurons: evidence favoring the dual-hit hypothesis of neurodegeneration. Hippocampus 26:980-994.

Hensen SM, Heldens L, van Enckevort CM, van Genesen ST, Pruijn GJ, and Lubsen $\mathrm{NH}$ (2013) Activation of the antioxidant response in methionine deprived human cells results in an HSF1-independent increase in HSPA1A mRNA levels. Biochimie 95:1245-1251.

Hoffer ME, Balaban C, Slade MD, Tsao JW, and Hoffer B (2013) Amelioration of acute sequelae of blast induced mild traumatic brain injury by $\mathrm{N}$-acetyl cysteine: a double-blind, placebo controlled study. PLoS One 8:e54163.

Holmay MJ, Terpstra M, Coles LD, Mishra U, Ahlskog M, Öz G, Cloyd JC, and Tuite PJ (2013) N-acetylcysteine boosts brain and blood glutathione in Gaucher and Parkinson diseases. Clin Neuropharmacol 36:103-106.

Hou Y, Wang L, Yi D, Ding B, Yang Z, Li J, Chen X, Qiu Y, and Wu G (2013) Nacetylcysteine reduces inflammation in the small intestine by regulating redox, EGF and TLR 4 signaling. Amino Acids 45:513-522.

Huang J, Niknahad H, Khan S, and O'Brien PJ (1998) Hepatocyte-catalysed detoxification of cyanide by L- and D-cysteine. Biochem Pharmacol 55:1983-1990.

Huryn DM, Brodsky JL, Brummond KM, Chambers PG, Eyer B, Ireland AW, Kawasumi M, Laporte MG, Lloyd K, Manteau B, et al. (2011) Chemical methodology as a source of small-molecule checkpoint inhibitors and heat shock protein 70 (Hsp70) modulators. Proc Natl Acad Sci USA 108:6757-6762.

Jellinger KA (2009) Recent advances in our understanding of neurodegeneration. $J$ Neural Transm (Vienna) 116:1111-1162.

Jiang H, Wu YC, Nakamura M, Liang Y, Tanaka Y, Holmes S, Dawson VL, Dawson TM, Ross CA, and Smith WW (2007) Parkinson's disease genetic mutations increase cell susceptibility to stress: mutant $\alpha$-synuclein enhances $\mathrm{H}_{2} \mathrm{O}_{2}$ - and Sin-1induced cell death. Neurobiol Aging 28:1709-1717.

Jiang Y, Rumble JL, Gleixner AM, Unnithan AS, Pulugulla SH, Posimo JM, Choi HJ, Crum TS, Pant DB, and Leak RK (2013) $N$-acetyl cysteine blunts proteotoxicity in a heat shock protein-dependent manner. Neuroscience 255:19-32.

Jurkowska $\mathrm{H}$ and Wróbel M (2008) N-acetyl-L-cysteine as a source of sulfane sulfur in astrocytoma and astrocyte cultures: correlations with cell proliferation. Amino Acids 34:231-237.

Kalia SK, Kalia LV, and McLean PJ (2010) Molecular chaperones as rational drug targets for Parkinson's disease therapeutics. CNS Neurol Disord Drug Targets 9: $741-753$.

Kalia SK, Lee S, Smith PD, Liu L, Crocker SJ, Thorarinsdottir TE, Glover JR, Fon EA, Park DS, and Lozano AM (2004) BAG5 inhibits parkin and enhances dopaminergic neuron degeneration. Neuron 44:931-945.

Karg E, Tunek A, Brötell H, Rosengren E, and Rorsman H (1990) Alteration of glutathione level in human melanoma cells: effect of $\mathrm{N}$-acetyl-L-cysteine and its analogues. Pigment Cell Res 3:11-15.

Katz M, Won SJ, Park Y, Orr A, Jones DP, Swanson RA, and Glass GA (2015) Cerebrospinal fluid concentrations of $\mathrm{N}$-acetylcysteine after oral administration in Parkinson's disease. Parkinsonism Relat Disord 21:500-503. 
Kawamoto Y, Akiguchi I, Shirakashi Y, Honjo Y, Tomimoto H, Takahashi R, and Budka H (2007) Accumulation of Hsc70 and Hsp70 in glial cytoplasmic inclusions in patients with multiple system atrophy. Brain Res 1136:219-227.

Keck S, Nitsch R, Grune T, and Ullrich O (2003) Proteasome inhibition by paired helical filament-tau in brains of patients with Alzheimer's disease. J Neurochem 85:115-122.

Keller JN, Hanni KB, and Markesbery WR (2000) Impaired proteasome function in Alzheimer's disease. J Neurochem 75:436-439.

Kilpatrick K, Novoa JA, Hancock T, Guerriero CJ, Wipf P, Brodsky JL, and Segatori $\mathrm{L}$ (2013) Chemical induction of Hsp70 reduces $\alpha$-synuclein aggregation in neuroglioma cells. ACS Chem Biol 8:1460-1468.

Kimelberg HK and Nedergaard M (2010) Functions of astrocytes and their potential as therapeutic targets. Neurotherapeutics 7:338-353.

Komori T (1999) Tau-positive glial inclusions in progressive supranuclear palsy, corticobasal degeneration and Pick's disease. Brain Pathol 9:663-679.

Kondoh Y and Osada H (2013) High-throughput screening identifies small molecule inhibitors of molecular chaperones. Curr Pharm Des 19:473-492.

Lanneau D, Wettstein G, Bonniaud P, and Garrido C (2010) Heat shock proteins: cell protection through protein triage. Sci World $J$ 10:1543-1552.

Le W, Sayana P, and Jankovic J (2014) Animal models of Parkinson's disease: a gateway to therapeutics? Neurotherapeutics 11:92-110.

Leak RK (2014) Heat shock proteins in neurodegenerative disorders and aging. J Cell Commun Signal 8:293-310.

Leak RK, Castro SL, Jaumotte JD, Smith AD, and Zigmond MJ (2010) Assaying multiple biochemical variables from the same tissue sample. J Neurosci Methods 191:234-238.

Leak RK, Zigmond MJ, and Liou AK (2008) Adaptation to chronic MG132 reduces oxidative toxicity by a CuZnSOD-dependent mechanism. $J$ Neurochem 106 $860-874$

Lee HJ, Suk JE, Patrick C, Bae EJ, Cho JH, Rho S, Hwang D, Masliah E, and Lee SJ (2010) Direct transfer of $\alpha$-synuclein from neuron to astroglia causes inflammatory responses in synucleinopathies. J Biol Chem 285:9262-9272.

Leu JI and George DL (2007) Hepatic IGFBP1 is a prosurvival factor that binds to BAK, protects the liver from apoptosis, and antagonizes the proapoptotic actions of p53 at mitochondria. Genes Dev 21:3095-3109.

Leu JI, Pimkina J, Frank A, Murphy ME, and George DL (2009) A small molecule inhibitor of inducible heat shock protein 70. Mol Cell 36:15-27.

Leu JI, Pimkina J, Pandey P, Murphy ME, and George DL (2011) Heat shock protein70 inhibition by the small-molecule 2-phenylethynesulfonamide impairs protein clearance pathways in tumor cells. Mol Cancer Res 9:936-947.

Li XP, Xie WJ, Zhang Z, Kansara S, Jankovic J, and Le WD (2012) A mechanistic study of proteasome inhibition-induced iron misregulation in dopamine neuron degeneration. Neurosignals 20:223-236.

Lindersson E, Beedholm R, Højrup P, Moos T, Gai W, Hendil KB, and Jensen PH (2004) Proteasomal inhibition by $\alpha$-synuclein filaments and oligomers. J Biol Chem 279:12924-12934.

Liu T, Daniels CK, and Cao S (2012) Comprehensive review on the HSC70 functions, interactions with related molecules and involvement in clinical diseases and therapeutic potential. Pharmacol Ther 136:354-374

López Salon M, Morelli L, Castaño EM, Soto EF, and Pasquini JM (2000) Defective ubiquitination of cerebral proteins in Alzheimer's disease. J Neurosci Res 62 $302-310$

Lowe J, McDermott H, Pike I, Spendlove I, Landon M, and Mayer RJ (1992) $\alpha \mathrm{B}$ crystallin expression in nonlenticular tissues and selective presence in ubiquitinated inclusion bodies in human disease. J Pathol 166:61-68.

Lu CY, Yi PL, Tsai CH, Cheng CH, Chang HH, Hsiao YT, and Chang FC (2010) TNF$\mathrm{NF}-\kappa \mathrm{B}$ signaling mediates excessive somnolence in hemiparkinsonian rats. Behav Brain Res 208:484-496.

Maharjan S, Oku M, Tsuda M, Hoseki J, and Sakai Y (2014) Mitochondrial impairment triggers cytosolic oxidative stress and cell death following proteasome in hibition. Sci Rep 4:5896.

Martínez-Banaclocha M (2016) Cysteine Network (CYSTEINET) dysregulation in Parkinson's disease: role of N-acetylcysteine. Curr Drug Metab 17:368-385.

Martínez-Banaclocha MA (2012) $N$-acetyl-cysteine in the treatment of Parkinson's disease. What are we waiting for? Med Hypotheses 79:8-12.

Massey AJ, Williamson DS, Browne H, Murray JB, Dokurno P, Shaw T, Macias AT Daniels Z, Geoffroy S, Dopson M, et al. (2010) A novel, small molecule inhibitor of Hsc70/Hsp70 potentiates Hsp90 inhibitor induced apoptosis in HCT116 colon carcinoma cells. Cancer Chemother Pharmacol 66:535-545.

Masukawa T, Sai M, and Tochino Y (1989) Brain glutathione and the anti-hypoxic effect of glutathione depletors in mice. Jpn J Pharmacol 51:125-127.

McCarthy KD and de Vellis J (1980) Preparation of separate astroglial and oligodendroglial cell cultures from rat cerebral tissue. J Cell Biol 85:890-902.

McNaught KS (2004) Proteolytic dysfunction in neurodegenerative disorders. Int Rev Neurobiol 62:95-119.

McNaught KS, Belizaire R, Isacson O, Jenner P, and Olanow CW (2003) Altered proteasomal function in sporadic Parkinson's disease. Exp Neurol 179:38-46.

Messina S, Molinaro G, Bruno V, Battaglia G, Spinsanti P, Di Pardo A, Nicoletti F, Frati L, and Porcellini A (2008) Enhanced expression of Harvey ras induced by serum deprivation in cultured astrocytes. $J$ Neurochem 106:551-559.

Milan E, Perini T, Resnati M, Orfanelli U, Oliva L, Raimondi A, Cascio P, Bachi A, Marcatti M, Ciceri F, et al. (2015) A plastic SQSTM1/p62-dependent autophagic reserve maintains proteostasis and determines proteasome inhibitor susceptibility in multiple myeloma cells. Autophagy 11:1161-1178.

Mishto M, Bellavista E, Santoro A, Stolzing A, Ligorio C, Nacmias B, Spazzafumo L, Chiappelli M, Licastro F, Sorbi S, et al. (2006) Immunoproteasome and LMP2 polymorphism in aged and Alzheimer's disease brains. Neurobiol Aging 27:54-66

Miyata Y, Rauch JN, Jinwal UK, Thompson AD, Srinivasan S, Dickey CA, and Gestwicki JE (2012) Cysteine reactivity distinguishes redox sensing by the heat-inducible and constitutive forms of heat shock protein 70. Chem Biol 19: 1391-1399.

Monti DA, Zabrecky G, Kremens D, Liang TW, Wintering NA, Cai J, Wei X, Bazzan AJ, Zhong L, Bowen B, et al. (2016) N-acetyl cysteine may support dopamine neurons in Parkinson's disease: preliminary clinical and cell line data. PLoS One 11:e0157602

Morimoto RI (2008) Proteotoxic stress and inducible chaperone networks in neurodegenerative disease and aging. Genes Dev 22:1427-1438.

Needham PG, Mikoluk K, Dhakarwal P, Khadem S, Snyder AC, Subramanya AR and Brodsky JL (2011) The thiazide-sensitive $\mathrm{NaCl}$ cotransporter is targeted for chaperone-dependent endoplasmic reticulum-associated degradation. J Biol Chem 286:43611-43621.

Orenstein SJ and Cuervo AM (2010) Chaperone-mediated autophagy: molecular mechanisms and physiological relevance. Semin Cell Dev Biol 21:719-726.

Pahan K, Sheikh FG, Namboodiri AM, and Singh I (1998) $N$-acetyl cysteine inhibits induction of NO production by endotoxin or cytokine stimulated rat peritoneal macrophages, $\mathrm{C}_{6}$ glial cells and astrocytes. Free Radic Biol Med 24:39-48.

Pajonk F, Riess K, Sommer A, and McBride WH (2002) N-acetyl-L-cysteine inhibits 26S proteasome function: implications for effects on NF- $\kappa$ B activation. Free Radic Biol Med 32:536-543.

Pan T, Kondo S, Zhu W, Xie W, Jankovic J, and Le W (2008) Neuroprotection of rapamycin in lactacystin-induced neurodegeneration via autophagy enhancement. Neurobiol Dis 32:16-25.

Petrucelli L, O'Farrell C, Lockhart PJ, Baptista M, Kehoe K, Vink L, Choi P, Wolozin B, Farrer M, Hardy J, et al (2002) Parkin protects against the toxicity associated with mutant $\alpha$-synuclein: proteasome dysfunction selectively affects catecholaminergic neurons. Neuron 36:1007-1019.

Phatnani H and Maniatis T (2015) Astrocytes in neurodegenerative disease. Cold Spring Harb Perspect Biol 7:a020628.

Pizzurro DM, Dao K, and Costa LG (2014) Astrocytes protect against diazinon- and diazoxon-induced inhibition of neurite outgrowth by regulating neuronal glutathione. Toxicology 318:59-68.

Pocernich CB and Butterfield DA (2012) Elevation of glutathione as a therapeutic strategy in Alzheimer disease. Biochim Biophys Acta 1822:625-630.

Pocernich CB, La Fontaine M, and Butterfield DA (2000) In-vivo glutathione elevation protects against hydroxyl free radical-induced protein oxidation in rat brain. Neurochem Int 36:185-191.

Poole LB (2015) The basics of thiols and cysteines in redox biology and chemistry. Free Radic Biol Med 80:148-157.

Posimo JM, Titler AM, Choi HJ, Unnithan AS, and Leak RK (2013) Neocortex and allocortex respond differentially to cellular stress in vitro and aging in vivo. PLoS One 8:e58596.

Posimo JM, Unnithan AS, Gleixner AM, Choi HJ, Jiang Y, Pulugulla SH, and Leak RK (2014) Viability assays for cells in culture. J Vis Exp 83:e50645.

Renkawek K, Bosman GJ, and de Jong WW (1994a) Expression of small heat-shock protein hsp 27 in reactive gliosis in Alzheimer disease and other types of dementia. Acta Neuropathol 87:511-519.

Renkawek K, Bosman GJ, and Gaestel M (1993) Increased expression of heat-shock protein $27 \mathrm{kDa}$ in Alzheimer disease: a preliminary study. Neuroreport 5:14-16.

Renkawek K, Stege GJ, and Bosman GJ (1999) Dementia, gliosis and expression of the small heat shock proteins hsp27 and alpha B-crystallin in Parkinson's disease. Neuroreport 10:2273-2276.

Renkawek K, Voorter CE, Bosman GJ, van Workum FP, and de Jong WW (1994b) Expression of alpha B-crystallin in Alzheimer's disease. Acta Neuropathol 87: 155-160.

Requejo R, Hurd TR, Costa NJ, and Murphy MP (2010) Cysteine residues exposed on protein surfaces are the dominant intramitochondrial thiol and may protect against oxidative damage. FEBS $J$ 277:1465-1480.

Reyes RC, Cittolin-Santos GF, Kim JE, Won SJ, Brennan-Minnella AM, Katz M, Glass GA, and Swanson RA (2016) Neuronal glutathione content and antioxidant capacity can be normalized in situ by $N$-acetyl cysteine concentrations attained in human cerebrospinal fluid. Neurotherapeutics 13:217-225.

Rideout HJ, Lang-Rollin IC, Savalle M, and Stefanis L (2005) Dopaminergic neurons in rat ventral midbrain cultures undergo selective apoptosis and form inclusions, but do not up-regulate iHSP70, following proteasomal inhibition. $J$ Neurochem 93 : 1304-1313.

Rideout HJ, Larsen KE, Sulzer D, and Stefanis L (2001) Proteasomal inhibition leads to formation of ubiquitin $/ \alpha$-synuclein-immunoreactive inclusions in PC12 cells. $J$ Neurochem 78:899-908.

Rideout HJ and Stefanis L (2002) Proteasomal inhibition-induced inclusion formation and death in cortical neurons require transcription and ubiquitination. Mol Cell Neurosci 21:223-238.

Rodriguez KA, Osmulski PA, Pierce A, Weintraub ST, Gaczynska M, and Buffenstein $\mathrm{R}$ (2014) A cytosolic protein factor from the naked mole-rat activates proteasomes of other species and protects these from inhibition. Biochim Biophys Acta 1842: 2060-2072

Samuni Y, Goldstein S, Dean OM, and Berk M (2013) The chemistry and biological activities of N-acetylcysteine. Biochim Biophys Acta 1830:4117-4129.

Sawada H, Kohno R, Kihara T, Izumi Y, Sakka N, Ibi M, Nakanishi M, Nakamizo T, Yamakawa K, Shibasaki H, et al. (2004) Proteasome mediates dopaminergic neuronal degeneration, and its inhibition causes $\alpha$-synuclein inclusions. J Biol Chem 279:10710-10719.

Saykally JN, Rachmany L, Hatic H, Shaer A, Rubovitch V, Pick CG, and Citron BA (2012) The nuclear factor erythroid 2-like 2 activator, tert-butylhydroquinone, improves cognitive performance in mice after mild traumatic brain injury. Neuroscience 223:305-314.

Schlecht R, Scholz SR, Dahmen H, Wegener A, Sirrenberg C, Musil D, Bomke J, Eggenweiler HM, Mayer MP, and Bukau B (2013) Functional analysis of Hsp70 inhibitors. PLoS One 8:e78443. 
Seidel K, Vinet J, Dunnen WF, Brunt ER, Meister M, Boncoraglio A, Zijlstra MP, Boddeke HW, Rüb U, Kampinga HH, et al. (2012) The HSPB8-BAG3 chaperone complex is upregulated in astrocytes in the human brain affected by protein aggregation diseases. Neuropathol Appl Neurobiol 38:39-53.

Sekihara K, Harashima N, Tongu M, Tamaki Y, Uchida N, Inomata T, and Harada M (2013) Pifithrin- $\mu$, an inhibitor of heat-shock protein 70, can increase the antitumor effects of hyperthermia against human prostate cancer cells. PLoS One 8:e78772.

Seo H, Sonntag KC, and Isacson O (2004) Generalized brain and skin proteasome inhibition in Huntington's disease. Ann Neurol 56:319-328.

Sheffner AL (1963) The reduction in vitro in viscosity of mucoprotein solutions by a new mucolytic agent, $N$-acetyl-L-cysteine. Ann N Y Acad Sci 106:298-310.

Shin Y, Klucken J, Patterson C, Hyman BT, and McLean PJ (2005) The co-chaperone carboxyl terminus of Hsp70-interacting protein (CHIP) mediates $\alpha$-synuclein degradation decisions between proteasomal and lysosomal pathways. J Biol Chem 280:23727-23734.

Shinohara H, Inaguma Y, Goto S, Inagaki T, and Kato K (1993) $\alpha \mathrm{B}$ crystallin and HSP28 are enhanced in the cerebral cortex of patients with Alzheimer's disease. $J$ Neurol Sci 119:203-208.

Snyder H, Mensah K, Theisler C, Lee J, Matouschek A, and Wolozin B (2003) Ag gregated and monomeric $\alpha$-synuclein bind to the $\mathrm{S}^{\prime}$ proteasomal protein and inhibit proteasomal function. J Biol Chem 278:11753-11759.

Steenvoorden DP and Beijersburgen van Henegouwen GM (1998) Glutathione synthesis is not involved in protection by $\mathrm{N}$-acetylcysteine against UVB-induced systemic immunosuppression in mice. Photochem Photobiol 68:97-100.

Stefanis L, Larsen KE, Rideout HJ, Sulzer D, and Greene LA (2001) Expression of A53T mutant but not wild-type $\alpha$-synuclein in PC12 cells induces alterations of the ubiquitin-dependent degradation system, loss of dopamine release, and autophagic cell death. J Neurosci 21:9549-9560.

Stein RL, Melandri F, and Dick L (1996) Kinetic characterization of the chymotryptic activity of the 20S proteasome. Biochemistry 35:3899-3908.

Strom E, Sathe S, Komarov PG, Chernova OB, Pavlovska I, Shyshynova I, Bosykh DA, Burdelya LG, Macklis RM, Skaliter R, et al. (2006) Small-molecule inhibitor of p53 binding to mitochondria protects mice from gamma radiation. Nat Chem Biol 2:474-479.

Sun F, Anantharam V, Zhang D, Latchoumycandane C, Kanthasamy A, and Kanthasamy AG (2006) Proteasome inhibitor MG-132 induces dopaminergic degeneration in cell culture and animal models. Neurotoxicology 27:807-815.

Sun L, Gu L, Wang S, Yuan J, Yang H, Zhu J, and Zhang H (2012) N-acetylcysteine protects against apoptosis through modulation of group I metabotropic glutamate receptor activity. PLoS One 7:e32503.

Tchantchou F, Graves M, Rogers E, Ortiz D, and Shea TB (2005) N-acteyl cysteine alleviates oxidative damage to central nervous system of ApoE-deficient mice following folate and vitamin E-deficiency. J Alzheimers Dis 7:135-138, discussion 173-180.

Titler AM, Posimo JM, and Leak RK (2013) Astrocyte plasticity revealed by adaptations to severe proteotoxic stress. Cell Tissue Res 352:427-443.

Tsai YC, Fishman PS, Thakor NV, and Oyler GA (2003) Parkin facilitates the elimination of expanded polyglutamine proteins and leads to preservation of proteasome function. J Biol Chem 278:22044-22055.

Tucker S, Ahl M, Cho HH, Bandyopadhyay S, Cuny GD, Bush AI, Goldstein LE Westaway D, Huang X, and Rogers JT (2006) RNA therapeutics directed to the non coding regions of APP mRNA, in vivo anti-amyloid efficacy of paroxetine, erythromycin, and N-acetyl cysteine. Curr Alzheimer Res 3:221-227.

Unnithan AS, Choi HJ, Titler AM, Posimo JM, and Leak RK (2012) Rescue from a two hit, high-throughput model of neurodegeneration with $\mathrm{N}$-acetyl cysteine Neurochem Int 61:356-368.

Unnithan AS, Jiang Y, Rumble JL, Pulugulla SH, Posimo JM, Gleixner AM, and Leak RK (2014) $N$-acetyl cysteine prevents synergistic, severe toxicity from two hits of oxidative stress. Neurosci Lett 560:71-76.

Uversky VN (2009) Intrinsic disorder in proteins associated with neurodegenerativeva diseases. Front Biosci (Landmark Ed) 14:5188-5238.

Wakabayashi K, Hayashi S, Yoshimoto M, Kudo H, and Takahashi H (2000) NAC$\mathrm{P} /$ alpha-synuclein-positive filamentous inclusions in astrocytes and oligodendrocytes of Parkinson's disease brains. Acta Neuropathol 99:14-20.

Walker LC, Levine H, III, Mattson MP, and Jucker M (2006) Inducible proteopathies. Trends Neurosci 29:438-443.

Wang J, Pareja KA, Kaiser CA, and Sevier CS (2014) Redox signaling via the molecular chaperone $\mathrm{BiP}$ protects cells against endoplasmic reticulum-derived oxidative stress. eLife 3:e03496.
Wilhelmus MM, Otte-Höller I, Wesseling P, de Waal RM, Boelens WC, and Verbeek MM (2006) Specific association of small heat shock proteins with the pathologica hallmarks of Alzheimer's disease brains. Neuropathol Appl Neurobiol 32:119-130.

Wispriyono B, Matsuoka M, Igisu H, and Matsuno K (1998) Protection from cadmium cytotoxicity by $\mathrm{N}$-acetylcysteine in LLC-PK $_{1}$ cells. J Pharmacol Exp Ther 287: 344-351.

Wyss-Coray T, Loike JD, Brionne TC, Lu E, Anankov R, Yan F, Silverstein SC, and Husemann $J$ (2003) Adult mouse astrocytes degrade amyloid- $\beta$ in vitro and in situ. Nat Med 9:453-457.

Xie W, Li X, Li C, Zhu W, Jankovic J, and Le W (2010) Proteasome inhibition modeling nigral neuron degeneration in Parkinson's disease. J Neurochem 115: 188-199.

Xilouri M and Stefanis L (2010) Autophagy in the central nervous system: implications for neurodegenerative disorders. CNS Neurol Disord Drug Targets 9: 701-719.

Yan CY, Ferrari G, and Greene LA (1995) $N$-acetylcysteine-promoted survival of PC12 cells is glutathione-independent but transcription-dependent. J Biol Chem 270:26827-26832.

Yan CY and Greene LA (1998) Prevention of PC12 cell death by $N$-acetylcysteine requires activation of the Ras pathway. $J$ Neurosci 18:4042-4049.

Yang W, Sopper MM, Leystra-Lantz C, and Strong MJ (2003) Microtubule-associated tau protein positive neuronal and glial inclusions in ALS. Neurology 61:1766-1773.

Yang W and Strong MJ (2012) Widespread neuronal and glial hyperphosphorylated tau deposition in ALS with cognitive impairment. Amyotroph Lateral Scler 13: 178-193.

Yi JH and Hazell AS (2005) $N$-acetylcysteine attenuates early induction of heme oxygenase-1 following traumatic brain injury. Brain Res 1033:13-19.

Yokota O, Tsuchiya K, Oda T, Ishihara T, de Silva R, Lees AJ, Arai T, Uchihara T, Ishizu H, Kuroda S, et al. (2006) Amyotrophic lateral sclerosis with dementia: an autopsy case showing many Bunina bodies, tau-positive neuronal and astrocytic plaque-like pathologies, and pallido-nigral degeneration. Acta Neuropathol 112: 633-645.

Yu X, Robinson JF, Sidhu JS, Hong S, and Faustman EM (2010) A system-based comparison of gene expression reveals alterations in oxidative stress, disruption of ubiquitin-proteasome system and altered cell cycle regulation after exposure to cadmium and methylmercury in mouse embryonic fibroblast. Toxicol Sci 114: $356-377$.

Zeng F, Tee C, Liu M, Sherry JP, Dixon B, Duncker BP, and Bols NC (2014) The p53/HSP70 inhibitor, 2-phenylethynesulfonamide, causes oxidative stress, unfolded protein response and apoptosis in rainbow trout cells. Aquat Toxicol 146: $45-51$.

Zhang F, Lau SS, and Monks TJ (2011) The cytoprotective effect of N-acetyl-L-cysteine against ROS-induced cytotoxicity is independent of its ability to enhance glutathione synthesis. Toxicol Sci 120:87-97.

Zhang NY, Tang Z, and Liu CW (2008) $\alpha$-Synuclein protofibrils inhibit $26 \mathrm{~S}$ proteasome-mediated protein degradation: understanding the cytotoxicity of protein protofibrils in neurodegenerative disease pathogenesis. $J$ Biol Chem 283: 20288-20298.

Zhang Y, Nijbroek G, Sullivan ML, McCracken AA, Watkins SC, Michaelis S, and Brodsky JL (2001) Hsp70 molecular chaperone facilitates endoplasmic reticulum-associated protein degradation of cystic fibrosis transmembrane conductance regulator in yeast. Mol Biol Cell 12:1303-1314.

Zhang Z, Li X, Xie WJ, Tuo H, Hintermann S, Jankovic J, and Le W (2012) Antiparkinsonian effects of Nurr1 activator in ubiquitin-proteasome system impairment induced animal model of Parkinson's disease. CNS Neurol Disord Drug Targets 11:768-773.

Zhou J, Coles LD, Kartha RV, Nash N, Mishra U, Lund TC, and Cloyd JC (2015) Intravenous administration of stable-labeled N-acetylcysteine demonstrates an indirect mechanism for boosting glutathione and improving redox status. J Pharm Sci 104:2619-2626.

Zhu W, Li X, Xie W, Luo F, Kaur D, Andersen JK, Jankovic J, and Le W (2010) Genetic iron chelation protects against proteasome inhibition-induced dopamine neuron degeneration. Neurobiol Dis 37:307-313.

Address correspondence to: Dr. Rehana K. Leak, 407 Mellon Hall, Pharmacy, 600 Forbes Avenue, Duquesne University, Pittsburgh, PA 15282. E-mail: leakr@duq.edu 